\title{
ADVERSE CLAIMS UNDER THE UNIFORM COMMERCIAL CODE: A SURVEY AND PROPOSALS*
}

THE "adverse claim" situation presents problems as vexing as any encountered in the law of commercial paper. ${ }^{1}$ The participants in this recurring situation are three: the payor, the claimant and the holder. The party against whom claims are asserted is the payor, who owes a duty of performance to the holder of a negotiable instrument. The performance owed may be the payment of money, registration of securities or delivery of goods. Before the holder presents the instrument to the payor, an adverse claimant informs the payor that he claims a right to the performance owed which is superior to the right of the holder. The payor is generally a disinterested stakeholder: he concedes that a performance is due, and insists only that no more than one of the parties is entitled to it. The claimant, who may or may not be a party to the instrument, typically bases his claim to the instrument or its proceeds on such allegations as theft, mistake, fraud, or breach of fiduciary duty. ${ }^{2}$ The holder may contest the claim by denying the claimant's allegations or by asserting that, whether or not the allegations are true, he is a good faith purchaser who holds the instrument free of claims. ${ }^{3}$

The draftsmen of the Uniform Commercial Code have attempted to deal with variations of the adverse claim problem in their institutional settings. Accordingly, the solution dictated by the Code in particular instances may de-

*Anerican Law Institute \& National Conference of Commissioners on Uniforar STATE Laws, Uniform CoMmerctal Code (hereinafter cited as U.C.C.). Unless otherwise stated, references are to the 1952 text and comments edition as finally approved in 1953. Previous tentative drafts will be cited to the month and year (e.g., U.C.C. (May 1949)). Amendments recommended by the Enlarged Editorial Board of the Code were printed in Supplement No. 1, Uniform CoMmercral Code (1955) (hereinafter cited as 1955 Supp.). The Supplement also contains recommendations and replies to criticisms of the various subcommittees. 1955 Supp. 89-189.

The 1952 draft of the Uniform Commercial Code has been adopted in Pennsylvania. PA. Stat. Ann. tit. 12A, $\$ \S 1-101-10-104$ (1954). As amended, it is being considered by the legislatures of many other states. The New York Law Revision Commission, after extended study of each article of the Code, has recently recommended that the New York Legislature not adopt the Code in its present form. N.Y. Times, March 12, 1956, p. 35, col. 6 .

1. While adverse claims may arise to property or choses in action which are not represented by negotiable instruments or documents of title, these claims are not within the scope of this comment.

2. The claimant may be the true owner of stolen goods. When he makes his claim, it is as legal owner; theft vests no legal title in the transferee. See U.C.C. $\$ 7-503(1)$. On the other hand, the claimant may be a former holder or indorser of the instrument claiming an equitable interest in it on the ground that it was improperly taken from him. For a catalogue of the different situations in which equities of ownership may arise see BritTon, BILls aNd Notes $\$ 155$ (1943) (hereinafter cited as BrITtoN).

3. The "bona fide" holder or holder "in due course" is of course permitted by his bona fides and the needs of commercial fluidity to take free of almost all the equities of 
pend on whether the stakeholder is the payor of a negotiable instrument under Article $3,{ }^{4}$ the drawee bank in a checking transaction within the scope of Article 4,5 the transfer agent of investment securities under Article $8,{ }^{\circ}$ the issuer of a letter of credit under the provisions of Article $5,{ }^{7}$ or a warehouseman or carrier governed by Article 7.8 But while solutions vary with institutional settings, they all deal with the same basic policy conflict. ${ }^{9}$ Each of the Code's solutions to particular adverse claim problems thus represents a compromise between (1) the desire to maintain honesty in transactions involving commercial paper; (2) the policy of facilitating the use and negotiation of commercial paper: and (3) the need to avoid undue disruption of the flow of commercial transactions. In the adverse claim situation, these policies are invoked primarily by the claimant, the holder and the stakeholder, respectively.

The claimant demands an opportunity to assert his equities against the holder; and, more than this, to assert his equities before the holder has dissipated the proceeds or the goods represented by the instrument. His claim is supported by the need to maintain honesty, an objective in both commercial and noncommercial transactions. However, only in the latter context is this goal untempered by competing demands. In the business context the need for honesty is no less urgent, but must be reconciled with the dictates of commercial expediency and ease of negotiability. ${ }^{10}$

The holder, in demanding immediate payment, asserts the community's interest in facilitating the use of commercial paper. Supporting his claim is the well established premise that commercial transactions would be seriously impeded unless the law minimized the risks involved in the purchase and transfer of negotiable instruments. Those sections of the Code which set out the rights

ownership. See, generally, Gilmore, The Commercial Doctrine of Good Faith Purchase, 63 Y Ale L.J. 1057 (1954).

4. Article 3 replaces the Uniforar Negomable Instrunints Law (hereinafter cited as N.I.L.), which is now in force in every state except Pennsylvania. See U.C.C. \$ 3-101, comment; pp. 810-16 infra.

5. Article 4 contains the bank collection provisions of the Code, which take priority over inconsistent provisions in Article 3. U.C.C. \$ 4-102(1). See pp. \$16-29 infra.

6. Article 8 deals with investment securities, presently covered by the N.I.L. and the UNIFoRM STOCK TRANSFER ACT (hereinafter cited as U.S.T.A.). U.C.C. \$ 8-101, comment. See pp. 829-33 infra.

7. U.C.C. $\$ \$ 5-103(1)(a)$, (b), (c). See pp. 833-39 infra.

8. Article 7 replaces the UnIform WAREHouse Recerpts Act, the Uniford Bills: of LAding ACT and relevant provisions of the UnIFord SALES ACT. U.C.C. § 7-101, comment. See pp. 839-44 infra.

9. The code is largely predicated on the principle that a unifying theme underlies much of commercial law. See U.C.C., comment pp. 2, 7; Leary, Article 4: Bank Dcposits and !Collections Under the Uniform Commercial Code, 15 U. PrTT. L. Rev. 565 (1954); Littleton, Article 7: Documents of Title, $15 \mathrm{id}$. at 595; Llewellyn, IThy a Commcrial Code? 22 Tenn. L. Rev. 779 (1953).

10. See Texas Legislative Council, Analysis of Article 7 of the Uniforai Conmerclal Code 141-42 (1952) ; Britton, Holder in Due Course, 49 Nw. U.L. Rev. 417, 418 (1954) ; Strahorn, The Policy or Function of the Law of Bills and Notes, 87 U. P.. L. KEv. $662-63(1939)$. 
of the bona fide purchaser expressly recognize this policy, ${ }^{11}$ which has grown in importance throughout the history of the commercial law. ${ }^{12}$ Traditionally, this policy is implemented by allowing the holder in due course to take free of most defenses and claims, ${ }^{13}$ and by according to the holder's claim substantial presumptions of validity. ${ }^{14}$ But in the adverse claim situation, the holder may well demand more. As presumptive owner, he should be entitled to payment unless his adversary initiates legal action and persuades a court of the validity of his claim. The holder certainly cannot demand immunity from legal action, but he may well ask that the mere assertion of an adverse claim should not shift to him the burden of initiating litigation to obtain payment.

The stakeholder's dilemma is perhaps the most familiar aspect of the adverse claim situation. The stakeholder ordinarily has no direct interest in the claimant-holder dispute; he wants only to render the promised performance and thereupon to obtain a discharge, leaving the disputants to settle their controversy between themselves. To satisfy these reasonable demands is to preserve intact the normal flow of commercial transactions, and to avoid imposing on a neutral party the vexation and expense of a controversy in which he has no real concern. ${ }^{16}$ Yet the stakeholder's demands are not always met. The claimant's natural adversary, the holder, is often unknown or beyond the reach of service of process, so that the claim must be made effective, if at all, through the stalieholder, before the holder presents the instrument for payment. ${ }^{16}$ But

11. See U.C.C. $\$ \$ 2-403$ (purchase of goods), 3-305 (holder in due course of commercial paper), 4-209 (bank as holder in due course), 5-111(1) (holder in due course under letter of credit), 7-502 (rights upon due negotiation of document of title), 8-301 (2) (bona fide purchaser of investment security).

12. The development of the law is dramatically described by Gilmore, supra note 3 .

13. See, e.g., U.C.C. sections cited at note 11 supra. Section 3-305(2) states the socalled "real" defenses to which a holder in due course is subject. A discussion of defenses and claims in commercial paper is found in Britton, Defenses, Claims of Ozonership and Equitics-A Comparison of the Negotiable Instruments Law with Corresponding Provisions of Article 3 of the Proposed Commercial Code, 7 Hastrangs L.J. 1 (1955.).

14. For a discussion of substantive and procedural advantages awarded the holder of negotiable instruments, see Strahorn, sttpra note 10, at 664-80. Procedurally, the holder of a negotiable instrument is presumed prima facie to be a holder in due course. N.I.L. $\$ 59$; U.C.C. $\$ 3-307(3)$.

15. See, e.g., Merrill, Bankers' Liability for Deposits of a Fiduciary to His Personal Account, $40 \mathrm{H}_{\mathrm{AR}}$. L. REv. 1077, $1091-1109$ (1927). See also Empire Trust Co. v. Cahan, 274 U.S. 473 (1926). In the Cahan case a fiduciary had transferred trust funds to his personal account with the bank. The Second Circuit had held that the transfer imported notice to the bank of the fiduciary's intended misappropriation. Judge Hough phrased the issue as a choice between "business convenience and expedition, a liking for that which is 'practicable,' rather than that which is burdensomely altruistic," and "a desire to yield that measure of assistance which the law increasingly attempts to give to the victims of misplaced confidence." Cahan v. Empire Trust Co., 9 F.2d 713, 719 (2d Cir. 1926). The Supreme Court reversed. Justice Holmes adopted the view expressed by Judge Cardozo in Whiting v. Hudson Trust Co., 234 N.Y. 394, 406, 138 N.E. 33, 37 (1923) : "The transactions of banking in a great financial center are not to be clogged, and their pace slackened, by overburdensome restrictions."

16. See text at notes 20 (commercial paper), 72 (checks), 91 (bank deposits), 108 (fiduciary funds) and 125 (stock transfer) infra. 
the role which the stakeholder must play in this controversy should be minimal : he is in no position to resolve the dispute, and the possibility of double liability or vexation which present law often imposes is usually unjustifiable. ${ }^{17}$ In some instances, concededly, automatic discharge is undesirable. Certain losses are inherent in the use of negotiable instruments, and consequently should be allocated to the stakeholder because he is best able to insure against them and to distribute the cost over the segment of the community that utilizes his services. ${ }^{18}$ But absolute liability of this type should not be imposed on a stakeholder if the risk involved is not properly attributable to the type of commercial enterprise involved, ${ }^{19}$ or if the stakeholder's attempts to prevent liability by more careful inquiry would entail inordinate and cumbersome delays.

The success of the adverse claim provisions of the Code depends on the extent to which they reconcile the conflicting interests of the parties and the exigencies of the institutional practices involved. Solutions proposed by the applicable articles of the Code will be examined in the light of the general considerations discussed above, with detailed discussion of the problems peculiar to each.

\section{Article 3: Commercial Paper-The Keystone Provision}

In the classical adverse claim situation $A$ issues a note to $B$ who indorses it to $C$. $C$ either transfers to $D$ or presents the note himself. Before presentment, however, $B$ notifies $A$ that the transfer to $C$ is legally inoperative, and that he still retains a claim to the instrument.

Under existing law, although the dispute is between $B$ and $C$ (or $D$ ), the burden of resolving it is often placed on $A$. Section 119 of the Negotiable Instruments Law discharges $A$ from liability on the instrument only upon payment "in due course." and under section 88, payment in due course must be in good faith and without notice of a defect in the holder's title. ${ }^{20}$ Thus, if $B$ 's

17. It should be noted that proper solicitude for the needs of modern commerce does not require condoning dishonesty. The allegedly defrauded claimant must not be left without a remedy. The only question is whether that remedy should be pursued by interrupting the commercial process and imposing duties of inquiry on the commercial institutions through which the transactions are made or only by suit against the alleged defrauder or his assignees. The latter course would seem preferable so long as the claimant has an opportunity to serve process on the defrauder or transieree while the latter is in funds.

18. The classical example is allocation of forgery loss. See Comment, 62 YaLE L.j. 417, 435-38 (1953).

19. Cf. Ehrenzweig, Negligence Without Fatzi 61, 82-83 (1951) ; James, Accidcut Liability Reconsidered: The Impact of Liability Insurance, 57 YaLe L.J. 549, 550 (1948); Smith, Frolic and Detour, 23 Colum. L. Rev. 444, 716, 718 (1923); Comment, 42 MIcI. L. REv. 694 (1944).

20. Dewey v. Metropolitan Life Ins. Co., 256 Mass. 281,152 N.E. $\$ 2$ (1926) ; Gremberg v. World Exchange Bank, 227 App. Div. 413, 237 N.Y. Supp. 200 (1st Dep't 1929); Saint Paul-Mercury Indemnity Co. v. State Dep't of Agriculture, 259 Wis. 42, 47 N.W.2t 312 (1951). But sec Willoughby v. Newman, 46 Ga. App. 377, 167 S.E. 783 (1933). Payment to one in possession of a note, but not holding under a regular chain of indorse- 
claim proves to be justified, $A$ will remain liable to $B$ despite payment to the holder."1 But if $A$ refuses to pay and the holder then sues on the instrument, $A$ will not, in most states, be permitted to set up $B$ 's adverse claim as a defense. ${ }^{22}$ Even when he is allowed to assert $B$ 's claim, $A$ may lose to the holder on the merits; and because that judgment would not be binding on $B$, $A$ might incur a second liability in a suit by the adverse claimant. ${ }^{23}$ Under the better rule, he may interplead both the holder and the claimant; ${ }^{24}$ but the restrictions on interpleader, even under statute, seriously limit the efficacy of that remedy. ${ }^{25}$

ments may not work a discharge. First Nat'l Bank v. Gorman, 45 Wyo. 519, 21 P.2d 549 (1933). But see Modern Equipment Corp. v. Northern Trust Co., 284 Ill. App. 586, 1 N.E.2d 105 (1936).

$B$ may also place $D$ in a similar dilemma under N.L.L. $\$ 54$ which provides that a holder is "in due course" only to the extent that he has already given value on the instrument when he receives notice of an adverse claim. If $D$ has promised to give value to $C$ for the instrument, and is notified of $B$ 's claim before the value is actually given, $D$ will not be a holder in due course if $B$ 's claim is valid. On the other hand, $D$ will be liable to $C$ on the agreement if $B$ 's claim is invalid. If, however, $D$ 's promise to $C$ is represented by a negotiable instrument, the harshness of $\$ 54$ is mitigated; $D$ is considered to have given value. People's Sav. Bank v. Smith, 210 Iowa 136, 230 N.W. 565 (1930) ; Pennoyer v. Dubois State Bank, 35 Wyo. 319, 249 Pac. 795 (1926). The Code incorporates the Pennoyer holding. U.C.C. \$3-303(c).

21. Nielsen v. Planters Trust \& Sav. Bank, 183 La. 645, 164 So. 613 (1935) ; City of Brunswick v. Peoples Sav. Bank, 194 Mo. App. 360, 190 S.W. 60 (1916). Some courts, however, apparently have moderated the harshness of the N.I.L. result by ignoring the law when the claimant has refused to give indemnity. See Polotsky v. Artisans Sav. Bank, 37 Del. 151, 188 Atl. 63 (Super. Ct. 1936).

22. Bowles v. Oakman, 246 Mich. 674, 225 N.W. 613 (1929) (collecting citations); Reynolds v. Gregg, 258 S.W. 1088 (Tex. Civ. App. 1924). Contra, Brinley v. Williams, 189 Okla. 183, 114 P.2d 463 (1941).

The question involves N.I.L. \& 88 and the last sentence of N.I.L. $\$ 59$. The Commissioners' Note to $\$ 59$ implies that the intent was to deny the right of setting up third party claims. Brannan, Negotiable Instruments Law 884-91 (7th ed., Beutel 1948) (hereinafter cited as BEUTEL). See also BriTtoN \$ 159. The weight of authority under the common law was to the same effect. Kinney v. Kruse, 28 Wis. 183 (1871). For the common law minority rule, see Solomons v. Bank of England, 13 East 136, 104 Eng. Rep. 319 (K.B. 1791). See Note, Jus Teriii Under Common Law and the N.I.L., 26 Sr. JoHs's L. KEv. 135 (1951).

23. Britton § 159.

24. Fourth Nat'l Bank v. Lattimore, 168 Ga. 547, 148 S.E. 396 (1929) (claim of forgery) ; Welch v. Bank of the Manhattan Co., 264 App. Div. 906, 35 N.Y.S.2d 894 (2d Dep't 1942); Beutel $8 \$ 5$.

25. The purpose of interpleader is to relieve the stakeholder not only of double liability, but also of vexation arising from multiple suits. Sovereign Camp v. Partridge, 221 Ala. 75, 127 So. 505 (1930) ; Livingstone v. Bank of Montreal, 50 I11. App. 562, 566-67 (1893). Interyleader not only discharges the stakeholder but also cuts off any interest on the res from the time the funds are paid into court. Conner v. Bank of Bakersfeld, 183 Cal. 199, 190 Pac. 801 (1920).

In practice, however, the possibility of vexation alone does not always appear to be sufficient to allow interpleader. Lassiter v. Bank of Dawson, 191 Ga. 208, 11 S.E.2d 910 (1940) (interpleader denied despite explicit statutory provision); South Side Bank \& 
The Code has attempted to improve this situation by eliminating the requirement of payment "in due course." Under section 3-603, ${ }^{26}$ a fundamental change has been established: payment to the holder, ${ }^{27}$ even with knowledge of an adverse claim on the instrument, absolutely discharges the payor unless the adverse claimant takes affirmative action either to have payment enjoined or to provide the stakeholder with "adequate" indemnity. If the adverse claimant obtains process or indemnifies him, the stakeholder must refuse to pay the holder; he may then either move to interplead the parties or await legal action by the holder. If the stakeholder elects to defend against the holder's action, he will probably be able to assert the adverse claimant's equities as a defense, despite the general Code prohibition of the use of third party claims as defenses. ${ }^{28}$

Section 3-603 constitutes a significant step towards a desirable compromise between commercial expediency and honesty. The stakeholder need not be

Trust Co. v. Siefert, 223 Mo. App. 431, 18 S.W.2d 572 (1929). The four common law prerequisites to interpleader are: 1) the same debt must be claimed by the adverse parties; 2) the adverse titles must derive from a common source; 3 ) the stakeholder must have no interest in the subject matter; 4) the stakeholder must have incurred no independent liability to either of the claimants. 4 PoMreroy, EnutTy Jurisprudence $\$ \S 1323-26$ (5th ed. 1941) ; see Rauch v. Fort Dearborn Nat'l Bank, 223 IIl. 507, 79 N.E. 273 (1906). Even under statutes the stakeholder may still have to show that the adverse claims are "apparently well founded," Lassiter v. Bank of Dawson, supra, or that there are "debatable questions of law," Mandeville v. First Nat'1 Bank, 206 Ga. 426, 57 S.E.2d 553 (1950). See also note 95 infra. And the Federal Interpleader Act, 28 U.S.C. $\$ 1335$ (1952), has been construed to retain the rule that the stakeholder must be under no independent liability to any of the parties. Hurlbut v. Shell Oil Co., 131 F. Supp. 466 (W.D. La. 1955). Thus a paying bank, having accepted a draft on itself, would be unable to interplead unless it showed that no independent liability had thereby been incurred. First State Bank v. Citizens State Bank, 10 F.R.D. 424 (D. Neb. 1950), appeal dismissed, 191 F.2d 208 (8th Cir. 1951). But se' Note, 65 YALE L.J. 715 (1956).

The adverse claim treatment of the Code was intended to favor the use of interpleader, although there is no general interpleader statute. See U.C.C. $\$ \S 3-306$ (d), comment 5; 7-603, as amended 1955 Supp. (documents of title). Cf. Achtel v. Excelsior Sav. Bank, 133 N.Y.S.2d 450 (Sup. Ct. 1954).

26. "[T] he liability of any party is discharged to the extent of his payment or satisfaction to the holder even though it is made with knowledge of a claim of another person to the instrument unless prior to such payment or satisfaction the person making the claim either supplies indemnity deemed adequate by the party seeking the discharge or enjoins payment or satisfaction by order of a court of competent jurisdiction in an action in which the adverse claimant and the holder are parties." U.C.C. \$ 3-603(1).

27. Under U.C.C. $\$ 1-201(20)$, a holder must have possession of the item, and it must be indorsed to him or to bearer. This corresponds to definitions under existing law. U.C.C. 1-201, comment 20; N.I.I. \& 191.

28. Under U.C.C. $\$ 3-306$ (d) a claim of a third party to the instrument may not be asserted as a defense. This provision was inserted to protect the payor against a possible double liability to both the holder and the claimant. U.C.C. $\$ 3-306$, comment 5; see nott 25 supra and accompanying text. If the payor is indemnified, however, there is no longer any reason for protecting him and he should be allowed to assert the third party claim. This would follow existing law. Horrigan v. Wyman, 90 Mich. 121, 51 N.W. 137 (1892); - BEUTEL 885. 
concerned with third party claims and the threat of double liability. The claimant, who might otherwise be left with a worthless right against an insolvent or absconding defrauder, is given an opportunity to prove his allegations before payment is made. And the holder is protected against frivolous claims by the requirement that the claimant post bond or initiate suit in order to make his claim effective. ${ }^{20}$

But while section 3-603 does make substantial improvements on existing law, it nevertheless contains serious inadequacies and ambiguities. The adverse claimant is allowed to prevent payment to a holder by obtaining a court order, presumably a temporary or preliminary injunction, in a suit against the holder. But this remedy will not be available when, as is often the case, the adverse claimant is unable to locate or serve process on the holder before presentment. Furthermore, even if service is obtained, temporary injunctions are not immediately granted $;^{30}$ and it is unclear whether the stakeholder, if notified that proceedings for injunction are pending, must defer payment until an injunction is issued or denied. Finally, even if an injunction could be granted in time, section 3-603 does not establish the criteria by which to determine whether a restraining order should be granted; the problem is left entirely to the varying standards of local law. ${ }^{31}$

As a practical matter, most claimants will probably indemnify the stakeholder rather than seek a judicial order restraining payment. But this course of action will lead to problems of equal difficulty. Section 3-603 does not indicate what amount of indemnity, if any, must be "deemed adequate" by the

29. Originally, the section did not provide for indemnity or injunction remedies. U.C.C. art. 3, \$ \$03 (194\$). The 1952 provision substantially follows the suggestions outlined in Comment, Automatic Discharge of Negotiable Instrumtents in the Proposed Commercial Code, 44 IrL. L. REv. \&8 (1949). The writer of the comment sets out the competing policy factors and summarizes the debates of the draftsmen in adopting the basic provisions of $\S 3.603$.

30. Temporary injunctions may be issued immediately, but generally are not given prior to a weighing of the equities by the chancellor. Especially when contested by the parties, this determination should not and generally will not be made summarily. See MicClintock, EQuity 51-52, 383, 388-89 (2d ed. 1948); WALSH, EQUiTy 297-98 (1930). A preferable rule in this situation would be an automatic grant of the injunction subject to subsequent contempt citation if the court's process was abused. See note 38 infra and accompanying text.

31. It seems quite likely that some courts will not give temporary injunctions freely enough, or will subject them to ad hoc qualifications in line with the courts' views as to the probable outcome of a trial on the merits. See Leeds v. Guaranty Trust Co., 193 Misc. 681, 85 N.Y.S.2d 70 (Sup. Ct. 1948), an action brought by an adverse claimant to a bank deposit under N.Y. BANKING LAw \$ 134(5), similar to U.C.C. \$ 3-603. The plaintiff sought to enjoin the bank from paying the contents of the deposit to the depositor. The court determined that the claimant, in order to obtain an injunction, would have to post security; the statutory provision allowing a restraining order, although phrased in mandatory language, was nevertheless held to be subject to the discretion of the court, which could gear its relief to the nature of the claim. While the result seems sensible, it foreshadows disparate results under \$ 3-603. See also Solicitor v. Bankers Trust Co., 197 Misc. 381, 94 N.Y.S.2d 658 (Sup. Ct. 1949). 
stakeholder. Earlier drafts of the Code rejected the indemnity theory on the ground that only a law suit would enable the stakeholder to determine what amount of security would be "reasonable." 32 Since the term "claim" is not defined, it is not even clear when indemnity can be demanded under section $3-603 .^{33}$ At least when the adverse claim is based upon theft accompanied by forgery, the Code apparently retains the concept of payment "in due course." Thus a stakeholder bank might well prefer to refuse payment despite inadequate indemnity, and take the risk of nominal damages for wrongful dishonor. rather than to pay with knowledge of an adverse claim, and risk the double liability of payment without discharge. ${ }^{35}$

Finally, and most fundamentally, use of the indemnity feature places the holder in the tactically disadvantageous position of being forced to sue. ${ }^{30}$ The

32. Comment, 44 ILL. L. REv. 88, 97 (1949) (reviewing the "legislative history").

U.C.C. $\$ 3-419$ (2) states that liability in conversion is presumed not to exceed the face value of the instrument. However, the amount of the indemnity would probably have tu cover more than the value of the instrument. Under $\$ 4-103(5)$ the payor's "bad faith" could result in liability for damages exceeding the amount of the instrument. A drawee would also request to be indemnified against liability for wrongful dishonor of the drawer's check, which could greatly exceed the amount of the item under $\$ 4-402$. And certainly no stakeholder would consider himself adequately indemnified unless protected against the costs of litigation. See Britton, Defenses, Claims of Orenership and Equitics-A Comparison of the Provisions of the Negotiable Instruments Law wenth Corresponding Provisions of Article 3 of the Proposed Contmercial Code, 7 Hastings L.J. 1, 27 (1955).

33. Since the word "claim" is not defined in the Code, it would be necessary to resort to present law. Id. at 2 . Claim would encompass any equity of ownership resulting from fraud, and would also include a claim that bearer paper was stolen. U.C.C. $\$ \$ 3-305$ \& comment 2;3-306 \& comment 5. For the present state of the law, see BRirrun 734-37. If, however, the theft were accompanied by a forgery, $\$ 3-603$ would be inapplicalile. See note 34 infra.

34. U.C.C. $3-406$, as amended 1955 Supp.

The Code, adopting the prevailing rule, expressly provides that the payor remains liable to the claimant for payment over a forgery. U.C.C. $\$ 3-419$ (1) (c) ; Fourth Nat"1 Bank v. Lattimore, $168 \mathrm{Ga} .547,148$ S.E. 396 (1929). Further, the payor would have no right to recover payment against a holder in due course. U.C.C. \$ 3-418 (modifying the rule of Price v. Neal, 3 Burr. 354, 97 Eng. Rep. 871 (K.B. 1762)). The payor could, however, raise the forgery claim as a defense under $\S 3-307$ (1) (a) by not paying and requiring the holder to prove all prior signatures. For discussions of problems raised by checl: forgeries, see Kessler, Forged Indorsements, 47 YALE L.J. 863 (1938) ; Comment, 62 YaLI. L.J. 417 (1953).

35. Emblidge Reply, found in New YoRk LAw Revision CoMrmission, Study of Uniforas Commercial CODE 192, 197 (1954) (memoranda and hearings on Articles 3 and 4; hereinafter cited as N.Y. RePoRr) ; of. Beutel, The Proposed Uniform [?] Commercial Code Should Not Be Adopted, 61 YALE L.J. 334, 362 (1952). A court, impressed with the harshness of the rule in the case of payment to a "known thief" might narrowly construe $\$ 3-603$ or work an exception to it on an "abuse of legal rights" theory. Beutel, Comparison of the Proposed Commercial Code, Article 3, and the Negotiable Instrunnents Law. 30 Neb. L. Rev. 531, 553 (1951) ; cf. Nielsen v. Planters Trust and Sav. Bank, 183 La. 645, 164 So. 613 (1935). Liability for wrongful dishonor. though possibly very costly, is limited to actual damages to the drawer. U.C.C. $\$ 4402$.

36. The Code is not explicit, but presumably the holder would sue the payor if he were indemnified; the claimant-indemnitor would probably manage the defense. If the claimant 
claimant, whose equity may or may not be valid, gains the advantage of stopping payment without the necessity of proving his claim. This result is plainly inconsistent with the principle that the holder of a negotiable instrument has a prima facie right to recover. ${ }^{37}$ This principle, supported as it is by the policy of promoting free transferability, demands that the claimant should bear the burden of initiating suit.

The objections to both the injunction and indemnity devices can best be met by creating a new statutory remedy having some of the characteristics of both garnishment and interpleader. ${ }^{38}$ This remedy would enable the claimant to immobilize the proceeds of a disputed instrument until the holder could be served with process. The remedy would be granted only when the adverse

had obtained a temporary injunction (but see notes 30-31 supra and accompanying text), the holder probably would defend the action in which the injunction had been granted.

The burden of initiating litigation may, of course, be assumed by the payor in an interpleader suit. However, the payor is reimbursed for the cost of the litigation either under the indemnity bond if he chooses to stand suit and defend, or by recovering costs from the proceeds paid into court. United States v. Ullman, 115 F. Supp. 211 (E.D. Pa. 1953); Burks v. Burks, 222 Ark. 97, 257 S.W.2d 369 (1953). But see Century Ins. Co. v. First Nat'l Bank, 133 F.2d 789 (5th Cir. 1943) (bill in the nature of interpleader).

37. Compare U.C.C. $\$ 3-804$, which provides that if the claimant contends the instrument is lost, stolen or destroyed he may be forced to sue to obtain (although not necessarily to stop) payment. The comment to $\$ 3-804$ states that the claimant, because he is not a holder, is to be given no presumptions.

Under $\$ 3-\$ 03$ the party initiating suit could require all other intermediary parties who might be liable on the instrument to intervene. Service of process is not necessary if a written notice is sent to such persons. If they do not intervene (apparently whether or not they actually receive the notice, if reasonable steps are taken to have the notice delivered), they are nevertheless bound by the decision. Section 3-803 has, however, met with considerable criticisn on constitutional grounds. See Beutel, Comparison of the Proposid Commercial Code, Article 3, and the Negotiable Instruments Laz, 30 NEB. L. Rev. 531, 555-56 (1951); Milbank Mcmorandum, N.Y. Report 1024. For an excellent reply see Mentschikoff Memorandum, N.Y. RePoRT 67, 92-94.

38. The new statutory remedy described in text could be drafted substantially as follows:

Section 3-603. Adrcrse Clain to an Instrunent or Bank Deposit.

(1) The holder of a negotiable instrument shall be entitled to payment upon proper presentment, and upon payment the payor shall be discharged from any further liability, notwithstanding any third party claim, defense or equity to the instrument, or to the deposit on which the instrument is drawn, unless a writ of garnishment issued pursuant to subsection (2) has been properly served upon the payor.

(2) Any court of general jurisdiction in this state shall issue a writ of garnishment whenever any party:

(a) Files an affidavit with the court stating that he:

(i) has a specified claim of right to a specified instrument or deposit of funds payable by the payor;

(ii) has been unable, in the exercise of reasonable diligence, to serve process on the present holder of the instrument; and

(iii) will bring suit on the claim as specified as soon as jurisdiction over the person of the holder can be obtained; and

(b) Deposits a bond with the court to indemnify the holder against all damages and costs incurred by reason of the action taken by the claimant pursuant to this 
claimant declares by affidavit that he (1) has a specified claim to the instrument; (2) has been unable to serve process on the current holder despite due diligence; (3) will sue the holder on the claim when presentment for payment is made; and (4) has posted bond to indemnify the holder for costs if he fails to sustain his claim, and for attorney's fees if his claim is found to be merely colorable. Until served with the statutory writ of garnishment, the stakeholder would be unconditionally required to pay the holder at presentment. Once he had been served, however, he would not be permitted to pay the holder until the holder obtained dismissal of the writ of garnishment. Dismissal would be granted automatically two days after the holder filed an appearance or otherwise consented to jurisdiction over his person. Attachment of the proceeds should be made possible, at least to the extent normally allowed by local law. ${ }^{39}$

The proposed procedure would meet the legitimate needs of all parties to the adverse claim situation, without giving any one of them an unwarranted advantage. The stakeholder, who is not a party in interest to the dispute, could exercise no discretion and would incur no liability. The adverse claimant, who is a party in interest, would have the burden of beginning suit, but the assurance of payment if his claim were sustained. The holder, though he must submit himself to possible suit in the process of collection, would still retain all rights now accorded him by the Code, and would also be relieved from the necessity of commencing an action to enforce a claim which is presumed to be valid. Furthermore, the limitations on the remedy proposed would tend to discourage litigation of frivolous claims more effectively than the present indemnity provisions.

\section{Article 4: Bank Collections}

Article 4 deals with the most important facet of negotiable instruments law. the collection of checks. ${ }^{40}$ The low cost, automation, speed and rapid turnover

section if the claimant fails to make good his suit; and a reasonable attorney's fec if it is adjudged that the adverse claimant's suit is without reasonable foundation.

(3) Dismissal of a writ of garnishment issued pursuant to subsection (2) shall be granted upon application by the holder if he:

(a) Files written consent to jurisdiction over his person in any action commenced by the claimant pursuant to subsection (2) (a) (iii); and

(b) Deposits the instrument in the registry of the court.

(4) If within two days thereafter the claimant shows to the court by affidavit that the proceeds of the instrument are subject to seizure by mesne process under the laws of this state, the instrument shall be collected, and the proceeds retained in the registry of the court pending disposition of the action. If the claimant fails to make such showing, thi holder shall be entitled to withdraw the instrument or any proceeds thereof.

39. It would seem advisable to allow each state to determine for itself on what conditions the adverse claimant should be entitled to have the proceeds paid into court pending litigation. Most states permit attachment on any contract claim against a nonresident defendant; other grounds include fraud, concealment and absconding. See, e.g., Conn. Gen. Stat. $\$ \$ 8022-73$ (1949) ; N.Y. Civ. Prac. Act \$ 903; Pa. Stat. Ann. tit. 12, $\$ \S 2741,2891$ (1951).

40. In addition to checks and other negotiable instruments Article 4 covers nonnegotiable instruments and investment securities which may be collected through banks. U.C.C. 
which characterize bank collections indicate the special necessity of an adverse claim solution consistent with the particular problems encountered in the banking context. ${ }^{41}$ The system should not contain an invitation to fraud, nor should banks, as the best media for risk distribution, escape liability for those losses which are inherent in the use of checks. However, banks handle millions of items daily, ${ }^{42}$ and more than $99 \mathrm{r} / 2$ per cent of all checks are honored without difficulty. These circumstances indicate the strong need for adverse claim provisions which will not impede the normal flow of banking items. ${ }^{43}$

The principal problems which arise under Article 4 of the Code derive from the failure of the draftsmen to deal explicitly with adverse claims. Section 3-603 applies, but only when it does not conflict with more specific provisions of the bank collection article.44 And while several provisions of that Article seem to demand results inconsistent with section 3-603, their import is far from clear.

The problems which arise under Article 4 are best discussed in terms of whether the claim is asserted by (1) the drawer against the payee or subsequent parties to the instrument; (2) the payee or his indorsee against subsequent holders; or (3) a claimant against the depositor-drawer. A fourth, related problem is presented by the Code's treatment of fiduciary deposits, which introduces the concept of "constructive" notice of adverse claims.

\section{Drawer v. Payee: The Stop Order}

The drawer's claim against the payee or holder is made in the form of a stop-payment order. ${ }^{45}$ It may be made for his own benefit or that of a sub-

$\$ 4-104 \&$ comment 4 . For a brief description of existing state law on bank collections, see Clarke \& Barley, Bank Depostts and Coldections 7-10 (1955) (hereinafter referred to as CLARKE \& BaILEY).

41. See Comment, 51 Yale L.J. 986, 1010 (1942). Much of existing law was formulated in a predominantly cash economy ; the transition to a credit economy involving great numbers of checking transactions has not been accompanied in every instance by similar changes in the law governing these transactions. Morrison \& Sneed, Bank Collections: The StopPayment Transaction-A Comparative Study, 32 Texas L. Rev. 259-60 (1954); Leary, Deferred Posting and Delayed Returns-The Current Check Collection Problem, 62 HARV. L. REv. 905, 909 (1949).

42. Bank debits in one year have been estimated at $\$ 2.8$ trillion, with approximately nine billion checks issued. Vergari, In Re Articles 3, 4, and 5, 28 TEMr. L.Q. 529 n.5 (1955). An estimated twenty-five million items are processed daily in over fourteen thousand banking institutions. Id. at 540. In 1953 the Chase National Bank reportedly paid 247 million checks through clearings alone, representing a value of $\$ 164$ billion. Milbank Memorandum, N.Y. REPORT 10,11. The constant increase in the use of checks in the modern economy is indicated by the fact that debits to demand deposit accounts in the United States rose from $\$ 757$ billion in 1943 to $\$ 1.9$ trillion in 1954. U.S. BuREAU of the Census, Statistical Abstract of the United States: 1955, at 430 (76th ed. 1955).

43. See Leary, supra note 41, at 912. See also U.C.C. \$ 4-213, comments 1.9; CLARKE \& BAILEY 2-7.

44. U.C.C. \& 4-102(1).

45. See U.C.C. $\$ 4-403$, as amended 1955 Supp.

For the prerequisites of a valid stop order under existing law, see Moore, Sussman 
sequent party, ${ }^{46}$ and his reason for stopping payment may or may not constitute a valid defense to the instrument. ${ }^{47}$ Whatever its basis, if the stop order arrives at the bank before the check is paid, it must be heeded. ${ }^{48}$ This absolute right of the claimant to prevent payment, unique in adverse claim situations, is justified conceptually on the theory that a check is merely an order to a debtor under a contractual obligation, and therefore may be revoked by the drawer-creditor at any time before payment. ${ }^{40}$ The payee or any subsequent holder is given no advantage by his status as holder. If payment is stopped, he must sue the drawer on the instrument. ${ }^{5}$

In practice, the stop order is inconsistent with the exigencies of modern check collection. The banks have often been unable, even in the exercise of due care, to perform this service imposed by law. ${ }^{51}$ Bank collection is largely a mechani-

\& Brand, Legal and Institutional Methods Applied to Orders to Stop Paynent of Checlis, 42 Y ALE L.J. 817, 825 (1933).

46. See, e.g., First Nat'l Bank v. Beier, 238 Iowa 280, 26 N.W.2d \$53 (1947) ; Brinley v. Williams, 189 Okla. 183, 114 P.2d 463 (1941); Mashek v. Leonard, 186 S.W.2d 745 (Tex. Civ. App. 1945).

47. See, e.g., Hiroshima v. Bank of Italy, 78 Cal. App. 362, 248 Pac. 947 (1926).

48. Acts constituting final payment are set out in U.C.C. $\$ 4-213(1)$, as amended 1955 Supp. The bank must honor the stop order if it has been received before the bank has taken action or decided to pay the item. U.C.C. \$ 4-303(1), as amended 1955 Surp. However, under the 1955 revisions the payor cannot heed a stop order after an irrevocable settlement of the item or after completion of the posting process. U.C.C. $\$ 4-213(1)$ (1955 Supr.).

49. Second Nat'1 Bank v. Meek Appliance Co., 244 S.W.2d 769 (Ky. 1951); Speroff v. First-Cent. Trust Co., 149 Ohio St. 415,79 N.E.2d 119 (1948); Thomas v. First Nat'1 Bank, 376 Pa. 181, $101 \mathrm{~A} .2 d 910$ (1954). In those states which under the common law regarded a check as a pro tanto assignment of the debt owed by the drawee, the stop order was not allowed. First Nat'l Bank v. Keith, 183 I11. 475, 56 N.E. 179 (1899); Loan \& Sav. Bank v. Farmers \& Merchants Bank, 74 S.C. 210, 54 S.E. 364 (1906).

50. The drawer is secondarily liable on the instrument. Western Title Ins. and Guaranty Co. v. Bartolacelli, 124 Cal. App. 2d 690, 269 P.2d 165 (1954); U.C.C. $\$ 3-413$; N.I.L. $\$ 61$. See Vergari, supra note 42 , at 550 .

51. Morrison \& Sneed, supra note 41 , at 300 . The bank may be liable to the drawer for payment even though the stop order failed to describe the item accurately. Comparc Kentucky-Farmers Bank v. Staton, 314 Ky. 313, 235 S.W.2d 767 (1951) (liability), with John H. Mahon Co. v. Huntington Nat'l Bank, 62 Ohio App. 261, 23 N.E.2d 638 (1939) (no liability).

Earlier drafts of the Code explicitly prohibited banks from using exculpatory clauses to limit their liability for inadvertent payment over stop orders. U.C.C. $\$ 4-202(3)$ (Spring 1950). Although this provision has been eliminated, the depositor may still recover if he can prove that the bank was negligent. U.C.C. $\$ 4-103$; CLARKE \& BaILEY 48. Exculpatory clauses in agreements with depositors have been struck down in a number of states even without statutory proscription. In Reinhardt v. Passaic-Clifton Nat'l Eank \& Trust Co., 16 N.J. Super. 430, 84 A.2d 741 (App. Div. 1951), aff'd, 9 N.J. 607, 89 A.2d 242 (1952), the court invalidated an exculpatory clause on a "no consideration" theory, and also suggested two other reasons which could be used to support the result reached: (1) the parties lack equal bargaining power, and (2) the quasi-public nature of banking prevents any contract to escape liability. Exculpatory clauses have also been held invalid in Hiroshima v. Bank of Italy, 78 Cal. App. 362, 248 Pac. 947 (1926); Calamita v. Tradesmens Nat'1 Bank, 135 Conn. 326, 64 A.2d 46 (1949); Speroff v. First-Cent. 
cal and departmentalized process which is and should be geared towards speedy and uninterrupted turnover of millions of items daily. ${ }^{52}$ Retention of the stop order subjects this process to the constant possibility of interruption, ${ }^{53}$ and often results in preventing discharge rather than stopping payment. ${ }^{54}$ Despite its practical inconvenience, however, the stop order feature has been retained by the Code as a service to which depositors are entitled and one which banks offer as an inducement to the use of checks by drawers. ${ }^{55}$ It has also been justified as a means of shifting an inherent risk of bank collection to the banks, ${ }^{56}$ and reducing litigation between parties dealing with checks. ${ }^{57}$

But stop orders may increase litigation. A bank which has paid a check over a stop order may, by subrogation, assert the rights of either the drawer or holder in order to prevent unjust enrichment. ${ }^{58}$ Under a breach of warranty of presentment theory, the bank may be able to recover from any party presenting an item for payment with knowledge of an outstanding stop order. ${ }^{59}$ In addition, if the bank credits the customer's account at payment, the customer may be forced to sue for a recredit. He may then be involved in proving issues more difficult than he had anticipated. He will carry the burden of

Trust Co., 149 Ohio St. 415, 79 N.E.2d 119 (1948) ; Thomas v. First Nat'l Bank, 376 Pa. 1\$1, 101 A.2d 910 (1954). They were upheld in Hodnick v. Fidelity Trust Co., 96 Ind. App. 342, 183 N.E. 488 (1932) ; Tremont Trust Co. v. Burack, 235 Mass. 398, 126 N.E. 782 (1920) ; Gaita v. Windsor Bank, 251 N.Y. 152, 167 N.E. 203 (1929).

52. See Leary, supra note 41 , at $909-17$.

53. Hearings, N.Y. REFORT 311-12.

54. Morrison \& Sneed, supra note 41, at 317-18; Comment, 20 U. CHI. L. REv. 667, 669 (1953).

55. U.C.C. \$ 4-403, comment 2; Note, The Effect of Exculpatory Clauses on Bank Stop Payment Orders, 44 ILL. L. REv. 530, 533 (1949).

56. See U.C.C. \$ 4-403, comment 2.

57. See Comment, 20 U. Chr. L. Rev. 667, 668 (1953).

58. U.C.C. $\$ 4-407$. Since the bank will not be certain of whose rights it will eventually assert, it will have to implead all parties concerned. See, e.g., Central Nat'l Bank v. International Sales Co., 87 Ohio App. 207, 91 N.E.2d 532 (1950). If the stop order is to be continued, this right of subrogation seems necessary to avoid unjust results. See, e.g., Chase Nat'l Bank v. Battat, 297 N.Y. 185, 78 N.E.2d 465 (1948) ; Third Nat'1 Bank v. Carver, 31 Tenn. App. 520, 218 S.W.2d 66 (1948).

59. There is authority to the effect that a paying bank may recover from a holder who knew of the stop order. Chase Nat'l Bank v. Battat, 105 N.Y.S.2d 13 (Sup. Ct. 1951); Mirfreesboro Bank \& Trust Co. v. Travis, 190 Tenn. 429, 230 S.W.2d 658 (1950); Morrison \& Sneed, supra note 41, at 308. Contra, Miller v. Chatham and Phenix Nat'l Bank, 126 Misc. 559, 214 N.Y. Supp. 76 (Sup. Ct. 1926). However, the decisions seem predicated on the grounds that the holder was not a bona fide purchaser for value, and that the drawee bank was being defrauded, rather than that knowledge of the stop order per se breached a warranty.

Under the 1952 draft, the holder presenting an item for payment warrants to his depository bank and to the payor that he has no knowledge of an "effective" stop payment order. U.C.C. $\$ \$ 3-417$ (1) (b), 4-207(1) (d). However, these provisions have met with serious objection. N.Y. Report 124-25; N.Y. City Bar Association Report on the Proposed Uniform Commerctal Code 27-2S (1953). They were deleted by the 1955 amendments, the draftsmen indicating an intention to revert to the common law "insofar as there are common law decisions on the question." 1955 SuPr. 31. 
proof of loss. If he asserts the bank's negligence, he will have the burden of proving the inadequacies of the bank's stop order procedure. ${ }^{60}$ Furthermore, complex problems of proof might arise if the drawer must disprove the bank's contentions that the stop order was not received in time. ${ }^{61}$ As a result, the paying bank is under pressure to litigate issues which under Article 3 were deemed not to be its concern.

It is doubtful that the loss resulting from a bank's failure to heed stop orders should be placed on the bank as an inherent risk of its business. The risk exists only because the law imposes it on the bank. ${ }^{62}$ Unlike the forgery situation, the dispute underlying the stop-payment order does not basically involve the use of a check. The drawer may stop payment because he has been defrauded, but the fraud could have been as easily perpetrated without a check. Indeed, the Code provisions which allow the bank to sue prior parties under subrogation or breach of warranty theories seem to recognize that the ultimate loss should not be placed on the banks. ${ }^{63}$

Stop orders have also been justified as a means of promoting the use of checks, rather than cash, in that they afford the drawer greater opportunity to withdraw from a transaction found to be fraudulent. ${ }^{84}$ But at the present stage of commercial development, the use of checks would not be materially impeded by elimination of the stop-payment order. It is equally important to the promotion of transferability that payees and indorsees take checks with some amount of certainty. Indeed, use of the stop-payment order often works to promote fraud by the drawer rather than to deter fraud by the holder." Checks are commonly considered to be the equivalent of final payment in cash, and not a trial purchase on credit. ${ }^{66}$ Existing law, under which the drawer of a check who is dissatisfied with the underlying transaction may force the

60. U.C.C. \$ 4-403(3). See Comment, 20 U. Crr. L. REv. 667, 676-77 (1953).

61. See Malcolm Letter, N.Y. REPORT 133, 145-54; note 48 supra and accompanying text.

62. See note 51 supra.

63. See ClaRKE \& BaILEY 127 ; notes 58-59 stpra and accompanying text.

64. Comment, 20 U. CHI. L. Rev. 667, 668 (1953).

65. See, e.g., Hearings, N.Y. REPORT 280, 311; Comment, 20 U. CHI. L. Rev. 667, 668 n.8 (1953). The editors of the Comment concluded that $\S 189$ of the N.I.L. might indicate a legislative determination that the drawer was more often defrauded than the payee. Ibid. But $\S 189$ was enacted with an eye to the drawee-payee relationship, and not the relationship between the drawer and the payee of his check. Caledonia Nat'l Bank v. McPherson, 116 Vt. 328, 331, 75 A.2d 685, 687-88 (1950) ; Mountaineer Engineering Co. v. Bossart, 133 W. Va. 668, 670, 57 S.E.2d 633, 634 (1950) ; In re Thornton's Guardianship, 243 Wis. 397, 405, 10 N.W.2d 193, 196 (1943) ; Aigler, Rights of Holder of Bill of Exchangc Against the Drazuee, 38 HARv. L. REv. 857, 884 (1925).

66. It is difficult to conclude that when a seller accepts a check as payment for the sale of goods the seller believes that the sale is "conditional" upon the buyer's decision not to stop payment on the check. Morrison \& Sneed, sttpra note 41, at 260, contend that the buyer assumes the risks of fraud and nonconformity of the goods when he pays "cash," but that the seller assumes these risks when he accepts a check. The latter may be true under existing law, but it cannot be reconciled with the seller's desire to receive an instrument with all the attributes of money. Id. at 261. 
payee or his indorsee to sue on the instrument, is inconsistent with sound commercial practice and should be changed.

The Code should recognize that the drawer is still an adverse claimant even though his claim is against a check he himself has written. Transferability of checks and ease of bank collection would be promoted by treating the check, for this purpose, as an irrevocable order by the drawer which entitles the holder to payment until his claim is disproved in court. ${ }^{67}$ The drawer should then be treated as any other adverse claimant. He could be permitted to indemnify the payor bank or obtain legal process to enjoin payment under section 3-603; or, preferably, he could be allowed to garnishee the proceeds under the statutory revision previously proposed. ${ }^{68}$ In the final analysis, however, the perpetuation of the stop-payment order is likely to turn upon whether most depositors, including the legislators who will pass on the Code, continue to feel that this is a right which they should have, ${ }^{69}$ even though as to banks it is a serious handicap and as to drawers it provides protection which may eventually prove to be illusory and misleading.

\section{Payee v. Holder}

A different type of adverse claim arises when the indorser of a check notifies the drawee bank of an alleged defect in the title of the present holder, a subsequent indorsee holding under the claimant's chain of title. Under present law, the adverse claimant cannot require the bank to stop payment on the check $;^{70}$ the bank's duty runs only to the owner of the deposit. ${ }^{71}$ Since, however, the drawee is under a duty to its customer to use care and good faith

67. This is not to say that, as regards the bank, a check should be treated as a pro tanto assignment from the drawer to the payee. $C f$. note 73 infra and accompanying text.

Since a check is not an assignment, a dissatisfied drawer would still be able to withdraw the funds in the underlying account before the check was presented. Consequently, elimination of the stop-payment order will not entirely solve the problem. However, this procedure involves too many vexations to the drawer. He may, for example, have a number of other checks outstanding against the underlying account which he cannot afford to dishonor. This procedure cannot, therefore, be considered a ready substitute for the stop-payment order.

68. See note 38 supre and accompanying text.

69. See, e.g., Hearings, N.Y. Report 277.

70. Blake v. Hamilton Dime Sav. Bank, 79 Ohio St. 189, 87 N.E. 73 (1908). See U.C.C. \& 3-603, comment 1 .

"[The claimant's] only recourse, if his endorsement was procured by fraud or on an illegal consideration . . . is against the endorsee. . . The bank should not be thrust against its will into the position of a contender with a third party whom it never knew, with whom it had no dealings and for whose presence in the controversy the [claimant] ... was solely responsible." Polotsky v. Artisans Sav. Bank, 37 Del. 151, 160, 188 At1. 63, 67 (Super. Ct. 1936). See also Kimbell Trust \& Sav. Bank v. Olsen, 239 I1l. App. 609 (1926).

71. Leary v. Citizens \& Manufacturers Nat'1 Bank, 128 Conn. 475, 23 A.2d 863 (1942) ; Henderson v. Lincoln Rochester Trust Co., 303 N.Y. 27, 100 N.E.2d 117 (1951); General Am. Life Ins. Co. v. Stadiem, 223 N.C. 49, 25 S.E.2d 202 (1943). When a stop arder is issued by the drawer on behalf of the payee, however, the bank will be liable to the payee if it fails to heed the stop order. Southern Bank \& Trust Co. v. Whited, 25 
in paying his checks, ${ }^{72}$ it is actually in the same dilemma as the maker of a note. It would not be directly liable to the holder if it refused to pay the instrument, for a check generally does not operate as an assignment to the holder of the debt owed to the drawer by the bank. ${ }^{73}$ But refusal to pay a properly presented check is a breach of duty to the drawer, which may subject the bank to substantial damages for slander of credit. ${ }^{74}$ On the other hand. payment to the holder will not necessarily discharge the bank. Although an adverse claim may be ineffective as a stop order, it can constitute such noticc of defect in the holder's title that payment could not be "in due course" for purposes of discharging the instrument. ${ }^{75}$ Thus the adverse claimant would not be barred from suing the drawer, who is secondarily liable on the check. ${ }^{78}$ And if the claimant should prevail, the bank would be liable to the drawer for a wrongful charge to his account. ${ }^{77}$

The Code changes existing law governing payee-holder disputes, but the extent of the change is not clear. Under section 3-603 the payment in due course requirement is eliminated $;^{78}$ payment to the holder would absolutely discharge the instrument, entitling the drawee to charge its customer's account, ${ }^{79}$ unless the adverse claim were accompanied by injunction or adequate indemnity. It seems possible, however, that the bank may be able to pay the holder and obtain discharge notwithstanding an offer of indemnity by the

Ala. App. 309, 145 So. 832 (1933) ; First Nat'l Bank v. Beier, 238 Iowa 280, 26 N.W.21 853 (1947).

72. Allen v. Bank of America Nat'l Trust \& Sav. Ass'n, 58 Cal. App. 2d 124, 127, 136 P.2d 345, 347 (1943) ; Steffen, Comarerctal and Investment Paper 648-49 (2d ed. 1954).

73. N.I.L. $\$ 189$; Marx v. Maddrey, 106 F. Supp. 535 (E.D.N.C. 1952); Hiroshima v. Bank of Italy, 78 Cal. App. 362, 248 Pac. 947 (1926) ; Mountaineer Engineering Co. v. Bassert, 133 W.Va. 668, 57 S.E.2d 633 (1950).

The holder will be permitted, however, to prove special circumstances indicating a contrary intent. And if he proves that an assignment of the deposit in fact was made, the drawee bank will be liable to him. Fourth Street Bank v. Yardley, 165 U.S. 634 (1897); Jones v. Walsh, 194 Miss. 247, 11 So. $2 d 908$ (1943); Green v. Brown, 22 S.W.2d 701 (Tex. Civ. App. 1929); see 2 Morse, Banks and Banking $\$ \$ 492,499,500$ (6th ed. 1928). The drawee may also incur a direct liability to the holder by accepting the check. Southard v. Camden Nat'1 Bank, 120 A.2d 221 (Me. 1956).

74. Jaselli v. Riggs Nat'l Bank, 36 App. D.C. 159 (1911); McFall v. First Nat'l Bank, 138 Ark. 370, 211 S.W. 919 (1919) ; Wildenberger v. Ridgewood Nat'l Bank, 230 N.Y. 425, 130 N.E. 600 (1921). But see Brown v. Bank of Minden, 167 La. 421,119 So. 413 (1928).

75. N.I.L. \$\$ 88, 119; Llop v. First Nat'1 Bank, 178 Misc. 436, 35 N.Y.S.2d 867 (Sup. Ct. 1942). For a pre-N.I.L. decision to the same effect, see Public Grain \& Stock Exchange v. Kune, 20 I11. App. 137 (1886). But cf. Polotsky v. Artisans Sav. Bank, 37 Del. 151, 188 Atl. 63 (Super. Ct. 1936).

76. N.I.L. $\$ 61$; Nielsen v. Planters Trust \& Sav. Bank, 183 La. 645,164 So. 613 (1935); see note 50 supra.

77. See, e.g., Silver v. Commonwealth Trust Co., 22 N.J. Super. 604,92 A.2d 152 (L. 1952), sustained on rehearing, 24 N.J. Super. 504, 94 A.2d 880 (L. 1953); Gates v. Bank of America Nat'l Trust \& Sav. Ass'n, 120 Cal. App. 2d 571, 261 P.2d 545 (1953). See also Answers of First National Bank of Boston, N.Y. REPORT 188, 192.

78. See note 26 supra.

79. U.C.C. § $4-401$. 
claimant. Section 4-203 of the Code provides that a bank can be given "notice" only by its immediate "transferor." 80 If this section were taken at face value, the claimant would seem unable to prevent payment to the holder except by injunction. ${ }^{81}$ However, it seems unlikely that section 4-203 will be construed literally. There are statutory arguments for limiting the section to intermediary rather than depositary or payor banks. The section was primarily aimed at facilitating the transmission of items between banks. ${ }^{82}$ The term "transferor" could therefore be limited to another bank; this definition would exclude the depositary bank from the immunity of the section, since its transferor was the holder rather than another bank. "Transferor" could also be limited to a bank not presenting for payment, on the theory that presentment is not a transfer for payment; $; 3$ this definition would exclude the payor bank, whose transferor did present for payment. Furthermore, the courts may take the view that, despite its language, section 4-203 simply was not intended to apply to the adverse claim situation. There is authority for this position in the "legislative history" of the Code. ${ }^{84}$ But if it was the intent of the draftsmen thus to restrict section 4-203, their intent was not made clear in the language of the section.

Article 4 should be amended to clarify the status of the adverse claimant and provide a procedure consistent with the needs of bank collection and the interests of the parties. Section 3-603, as has been seen, gives the claimant overly adequate remedies. ${ }^{85}$ Section $4-203$, however, if it were applied, would not give him remedies enough: the injunction remedy is inadequate when, as frequently happens, the holder is unknown or unavailable for service of process. Section 4-203 does enact a chain of command theory which, between banks, greatly facilitates the collection process; it should be retained to the extent that adverse claims should not affect an intermediary bank, which could

80. "Subject to the provisions of Article 3 concerning restrictive indorsements and subject to provisions of this Article concerning notice from prior indorsements . . . only a bank's transferor can give instructions which affect the bank or constitute notice to it and a bank is not liable to prior parties for any action taken pursuant to such instructions or in accordance with any agreement with its transferor." U.C.C. § 4-203, as amended 1955 Supp. (Italicized portions were added by the 1955 amendments.)

81. U.C.C. $\$ 4-303(1)$; Morrison \& Sneed, supra note 41, at 273; N.Y. Clearing House Stbcommittee, N.Y. REPORT 96, 101; Malcolm Letter, id. 133, 136; Brome Letter, id. 155, 158-59.

82. Clarke \& BatLey 43-44.

83. "Transfer" is defined in U.C.C. \$ 3-201 as a process which vests in the transferee such rights as the transferor had in the paper. Presentment for payment does not vest rights in the paper but rather extinguishes any rights which the holder may have had. Consequently, "transfer," used as a term of art, would exclude presentment for payment. However, "transfer" is often used loosely to include presentment for payment. U.C.C. $\$ 4207$ (2); ClaRke \& Balley 57.

84. In answer to queries as to the effect of $\$ 4-203$ on adverse claims, note 81 supra, the Code subcommittee on Article 4 read the section as based "on the normal situation" and not including adverse claims within its scope. Thus according to the subcommittee a bank would have to interplead as under existing law. 1955 Supp. 133-34.

85. See note 36 supra and accompanying text. 
then rely wholly on the instructions of the bank which transferred the instrument to it. But the payor bank should be subject to the proposed garnishment remedy. ${ }^{86}$ In this way, the automatic character of the collection process could be continued, subject to interruption only by legal notices with which banks are already familiar, ${ }^{57}$ and the claimant could be assured of financial as well as legal victory-if his claim is sound.

\section{True Ozener v. Drawer: Claims to the Deposit}

A third type of adverse claim arises when the drawer has negotiated a check and, before it is presented for payment, a third party who is a stranger to the instrument claims a legal or equitable title to the underlying deposit superior to that of the drawer-depositor. ${ }^{88}$ The claimant may contend that the deposit consists of proceeds wrongfully or mistakenly taken from him, ${ }^{80}$ or that an originally legal deposit is being diverted by the depositor, who is either a trustee or an agent of the claimant ("true owner"). ${ }^{90}$ His claim is not directly against the holder, but it will, if heeded, prevent the holder from being paid according to the terms of the check he holds.

Existing law, apart from statute, places the bank in a dilemma analogous to that of the primary obligor under sections 88 and 119 of the Negotiable Instruments Law. ${ }^{91}$ The bank is under a contractual duty to the depositor not only to pay his checks but also to protect his title. ${ }^{92}$ Refusal to honor the check in deference to an adverse claim subsequently proved invalid is a breach of duty to its customer, and would entail liability for slander of credit. ${ }^{\text {33 }}$ But

86. See note 38 supra.

87. See Answers of First National Bank of Boston, N.Y. Report 188, 212; Comment, 51 XaLE L.J. 986, 1008-09 (1942).

88. For the various situations in which adverse claims to bank deposits may arise see Comment, 21 U. Chi. I. Rev. 135, 136-37 (1953) ; Comment, 51 Yale L.J. 986, 987-91 (1942).

89. See, e.g., Northwestern Upholstering Co. v. First Nat'l Bank \& Trust Co., 193 Minn. 333, 258 N.W. 724 (1935) ; Fidelity \& Cas. Co. v. First Nat'l Bank \& Trust Co., 71 N.D. 415, 1 N.W.2d 401 (1941).

90. See, e.g., James Mills Orchard Co. v. Bank of America, 137 Cal. App. 299, 30 P.2d 626 (1934); Bank of Beaufort v. Commercial Nat'l Bank, 207 N.C. 216, 176 S.E. 734 (1934).

91. See note 20 supra and accompanying text.

92. See A. T. Albro Co. v. Union Dime Sav. Inst., 15 App. Div. 351, 44 N.Y. Supp. 150 (1st Dep't 1897) ; Cole v. Canadian Bank of Commerce, 115 Ore. 456, 239 Pac. 98 (1925) ; Comment, 30 Marg. L. Rev. 54, 60 (1946). Upon notice of the adverse claim, the bank must notify the depositor of the claim. Jaselli v. Riggs Nat'l Bank, 36 App. D.C. 159 (1911) ; cf. Detroit Sav. Bank v. Burrows, 34 Mich. 153, 159 (1876).

93. See note 74 supra and accompanying text.

The bank would probably prefer to pay a check drawn by its depositor than to honur the adverse claim. Comment, 51 Y ALE L.J. 986, 991, 1001 (1942); See Answirs of First National Bank of Boston, N.Y. REPoRT 188, 203. However, the bank cannot resort to the commercially desirable rule, adopted in England, that the contract between the bank and the customer is of such importance that a claim to a deposit will not justify the dishonoring of a check. Sims v. Bond, 5 Bar. \& Ad. 389, 110 Eng. Rep. 834 (K.B. 1833); Pacr. Banking 188 (4th ed. 1930). Disputes in which the bank is involved in England must be 
the bank would be liable to the claimant in tort if it allowed withdrawals which reduced the deposit below the amount of his claim and he subsequently proved to be true owner. ${ }^{04}$ The bank's logical remedy, interpleader, may be denied if the bank is independently liable to either party or has an adequate remedy at law, or if the adverse claim is adjudged to have no "reasonable" foundation. ${ }^{95}$ The case law today generally permits the bank to escape liability by compelling the claimant to present indemnity or to take legal action within a reasonable time $;^{96}$ indeed, the bank may take indemnity from either the drawer or the claimant or both. ${ }^{.7}$ But a "reasonable time" standard has proved to be a poor practical guide before litigation. ${ }^{98}$ To relieve the harshness and uncertainty of the case law, many jurisdictions have enacted an adverse claim statute with provisions similar to those of section 3-603 of the Code. ${ }^{99}$ This statute, however, explicitly excludes claims by beneficiaries of trust funds from its operation. 100

referred to an arbitrator. Trustee Savings Bank Act, 1863, 26 \& 27 VIcr., c. 87, § 48. However, what might be deemed an adverse claim to bank deposits in this country may be held to be only a dispute between the parties in which the bank should not be joined. Winter v. Winter [1946] K.B. 466 (C.A.).

94. Smith v. Security Bank \& Trust Co., 196 Ark. 685, 119 S.W.2d 556 (1938) ; Trinity Universal Ins. Co. v. First State Bank, 143 Tex. 164, 183 S.W.2d 422 (1944) ; 1 MorsE, Banks AND BANKIng $\$ 343$ (6th ed. 1928).

95. First State Bank v. Citizens State Bank, 10 F.R.D. 424 (D. Neb. 1950) (independent liability); Baden Bank v. Trapp, 180 S.W.2d 755 (Mo. Ct. App. 1944) (adequate remedy at law); Wall v. Wall, 181 S.W.2d 817 (Tex. Civ. App. 1944) (same); Citizens Bank v. Middlebrooks, 209 Ga. 330, 72 S.E.2d 298 (1952) (question of law must be reasonably debatable); White v. Bank of Angola, 130 Misc. 99, 223 N.Y. Supp. 508 (Sup. Ct. 1927) (bank must show claim was "substantial") ; cf. Mathot v. North River Bank, 16 N.Y. Civ. Proc. 314, 6 N.Y. Supp. 498 (City Ct. 1889). See note 25 supra and accompanying text.

96. Drumm-Flato Comm'n Co. v. Gerlach Bank, 107 Mo. App. 426, 81 S.W. 503 (1904) (reasonableness of time is jury question); Huff v. Oklahoma State Bank, 87 Okla. 7, 207 Pac. 963 (1922) (nine-day delay before payment to depositor allowed).

97. First Nat'l Bank v. Bache, 71 Pa. 213 (1872) ; Stair v. York Nat'1 Bank, 55 Pa. 364 (1867); Comment, 51 YaLE L.J. 986, 1006 (1942).

98. Comment, 21 U. CHI. L. Rev. 135, 140 (1953). For an excellent discussion of the bank's dilemma, see Gendler v. Sibley State Bank, 62 F. Supp. 805, 811-13 (N.D. Iowa 1945).

The time element is considerably more material when the claim involves a checking account than when it is made against a savings account. When the check is presented through a clearing house, however, the bank may attempt to give itself more time by sending the check back for later presentment, thus escaping a possible liability for wrongful dishonor while it ascertains the validity of the claim. Comment, 51 YALE L.J. 986, 996 (1942).

99. An adverse claim statute recommended by the American Bankers Association has been adopted, with modifications, in twenty-nine jurisdictions. 2 PATON, DIGEST 1657, 1658 (1942 ed.), \$ 6:3 (1955 Supp.). Under its terms, the bank is not affected by notice of an adverse claim until the claimant has enjoined payment to the depositor or has indemnified the bank against any loss, including liability for wrongful dishonor of the depositor's checks.

100. This holds true for twenty-five of the twenty-nine jurisdictions which have adopted the adverse claim statute; four make no explicit exception for fiduciary funds. MD. CODE 
The Code originally provided that an adverse claim to a deposit should not affect the bank unless the claimant served the bank with a court order restraining payment. ${ }^{101}$ The present draft has eliminated this section, and apparently leaves the problem as it exists under present law. The automatic discharge provision of section 3-603 is by its own terms limited to claims "to the instrument," and it seems unlikely that it will be applied to claims against an entire deposit. ${ }^{102}$ It is even more unlikely that section 4-203 will be held to apply. ${ }^{103}$ In jurisdictions where an adverse claim statute has already been enacted, the claimant would have to offer indemnity and the claim would then have the effect of a stop-payment order. If there were no local statute, however, the bank would probably be required to pay or refuse to pay at its peril. This result would also obtain, whether or not there were a statute, whenever the adverse claimant is the beneficiary of a trust. ${ }^{104}$

\section{Fiduciary Deposits and Constructive Knowledge of Adverse Claims: "True Owner" v. Holder, Trustee or Agent}

Notice imputed to a bank by law may operate as an adverse claim which binds the bank more effectively than claims actually asserted. Funds represented by a check or bank deposit are often affected with a trust or agency character. When a trustee or agent ("fiduciary"), ${ }^{105}$ entrusted by a beneficiary or principal ("true owner") with authority to manage his account, has abused his authority by diverting the funds to his own use, ${ }^{106}$ the true owner is seldom

ANn. art. 11, $§ 103$ (Flack 1951) ; Miss. ANN. CODE $\$ 5207$ (1942) ; N.Y. BANKING LAW $\S \S 134(5), 171(5), 239(5), 310(7 a) ;$ S. DAK. CODE $\$ 6.0416$ (1939).

101. U.C.C. art. $3, \S 748$ (1948).

102. Under the 1948 draft, see note 101 supra, the section governing adverse claims to bank deposits was separate from the section that is now $\$ 3-603$, see note 26 supra. The elimination of the former section would more reasonably imply an intent to leave existing law unchanged rather than to merge bank deposit claims into $\$ 3-603$. The tenor of the comments to $\$ 3-603$ indicates that the section was intended to deal with claims arising between an indorser and subsequent indorsees on the item, and not with claims which have no particular reference to any item drawn.

103. See note 84 supra and accompanying text.

104. See notes 100 supra, 105-19 infra and accompanying text.

105. Generally, under existing law, "trust" and "agency" funds are treated alike. Sce, e.g., UNIForM Frductaries ACT $\$ 1$ (agents, corporate officers, trustees are within the definition of "fiduciary") (hereinafter cited as U.F.A.) ; Merrill, Bankers" Liability for Deposits of a Fiduciary to His Personal Account, 40 Harv. L. Rev. 1077, 1078 (1927). However, some courts have sensed that the commercial nature of corporate accounts sets them apart from noncommercial trust accounts. See Evans v. Prentice, 79 A.2d 396, 397 (D.C. Munic. Ct. App. 1951) ; Boston Ins. Co. v. Wells Fargo Bank \& Union Trust Co., 80 Cal. App. 2d 59, 64, 181 P.2d 84, 87 (1947). See, generally, BrtTron \$ 118; 5A Mrchur, Banks and Banking 130-73 (1950 ed.) ; 3 Scotr, Trusts $\$ \$ 321-24.5$ (1939 ed.).

106. The diversion may take a number of forms. The fiduciary may either draw, indorse or cash a check for his own use although the funds in truth are not his to use. A special variation of the last two breaches of duty arises if the true owner, when he indorsce the check, states in the indorsement that the indorsee is the true owner's trustee or agent for collection. BRITTON $\$ 67-71$ (restrictive indorsements). Under N.I.L. $\$ 37$, a taker 
aware of the act constituting the breach of duty until the drawee bank has paid the instrument. ${ }^{107}$ The true owner may, however, attempt to shift the loss to the bank, alleging that the bank should be held liable to him as if it had been given actual and timely notice of his claim. And he may succeed. Under existing law payment will not discharge the drawee bank from liability to the true owner, even though the true owner has not directly asserted his claim, if the drawee is deemed to have had actual or constructive knowledge of the fiduciary's intended misappropriation. ${ }^{108}$

after a restrictive indorsement can acquire only the rights of the first indorsee, and may not become a holder in due course. First Nat'l Bank v. John Morrell \& Co., 53 S.D. 496, 221 N.W. 95 (1928) ; Gulbranson-Dickinson Co. v. Hopkins, 170 Wis. 326, 175 N.W. 93 (1919). The 1952 draft of the U.C.C. reversed the N.I.L. and expressly provided that subsequent takers could ignore the restrictive indorsement. U.C.C. \$ 3-206(c). See Britton, Transfers and Negotiations Under the Negotiable Instruments Lazo and Article 3 of the Uniform Commercial Code, 32 Texas L. Rev. 153, 167-71 (1953). The 1955 amendments reverted somewhat to the N.I.L. The new provisions subject subsequent takers, with the exception of intermediary and paying banks, to the rights of the restrictive indorser. U.C.C. $\$ \$ 3-205$ \& comment, 3-206 (1955 Supp.). The discussion which follows does not explicitly deal with, but is in most respects applicable to, the treatment of restrictive indorsements.

107. Merrill, supra note 105 , at 1093-96. The fiduciary's defalcations usually occur over an extended period of time and are seldom discovered until most of the damage has been done. See, e.g., Church of God in Christ v. Bank of Malvern, 212 Ark. 971, 208 S.W.2d 770 (1948). The true owner may have permitted the fraud over such a length of time that he is deemed estopped from asserting his claim. See, e.g., McNutt Oil \& Refining Co. v. Mimbres Valley Bank, 174 F.2d 311 (10th Cir. 1949) ; Clark-Kelley Livestock Auction Co. v. Pioneer Bank \& Trust Co., 228 La. 224, 81 So. $2 d 869$ (1955).

108. Under the U.F.A. the drawee is liable for payment of a check if it knows of the breach of trust, or if it has "knowledge of such facts that its action in paying the check amounts to bad faith." U.F.A. $\$ \$ 7$ (deposit in name of fiduciary as such), 8 (deposit in name of true owner), 9 (deposit in fiduciary's personal account). "Good faith" is defined in $\$ 1(2)$ as honesty in fact, regardless of negligence.

The ultimate question of what circumstances will give the bank notice is one of fact. Boston Ins. Co. v. Wells Fargo Bank \& Union Trust Co., 80 Cal. App. 2d 59, 181 P.2d S4 (1947); American Surety Co. v. Trenton State Bank, 323 Mich. 276, 35 N.W.2d 260 (1948). Constructive notice may be imputed from a number of circumstances. See, e.g., Hartiord Acc. \& Indemnity Co. v. Bradley, 211 Ark. 1069, 204 S.W.2d 792 (1947) (knowledge that funds are held in trust puts bank under greater duty of surveillance); Lynch v. Wells Fargo Bank \& Union Trust Co., 114 Cal. App. 565, 300 Pac. 74 (1931) (same) ; Torrence Nat'l Bank v. Enesco Federal Credit Union, 134 Cal. App. 2d 316, 285 P.2d 737 (1955) (overdraft creates duty to inquire into agent-drawer's authority); Risto v. First Nat'l Bank, 314 Ill. App. 403, 41 N.E.2d 556 (1942) ("suspicious" circumstances); Seaboard Surety Co. v. State Sav. Bank, 307 Mich. 48, 11 N.W.2d 321 (1943) (trust deposit in contravention of statute puts bank on inquiry); Dunagan v. Bushey, 152 Tex. 630, 263 S.W.2d 148 (1953) (corporate charter gives bank notice of directors' authority). Moreover, once a wrongful transaction has put the bank on inquiry, it may be on notice as to subsequent diversions, however unrelated to the first. Fidelity \& Deposit Co. v. Farmers' Bank, 44 F.2d 11 (8th Cir. 1930), cert. denied, 282 U.S. 901 (1931). Contra, Dockstader v. Erown, 204 S.W.2d 352 (Tex. Civ. App. 1947).

If the drawee bank has played a role beyond that of drawce only, e.g., receiving payment as a creditor of the fiduciary, it will be liable to the true owner regardless of knowledge if 
The Code seems to follow existing law although this type of adverse claim is not specifically treated. A broad reading of section 3-603 would foreclose recovery by the true owner unless he had indemnified the bank or enjoined payment even if the bank had knowledge of a breach of trust. ${ }^{103}$ However, section 3-603 applies only to claims "to the instrument." It can therefore be interpreted to include only disputes between an indorser and subsequent indorsees of an instrument, and not claims made by a beneficiary or principal against an underlying deposit. ${ }^{110}$ Because the claimant will seldom have an opportunity to assert his claim before payment, ${ }^{111}$ it seems unlikely that the courts will find a legislative intent to bind the true owner by a statute he will generally be unable to utilize. Nor does section 4-203, which entitles a bank to ignore any notice not given to it by its immediate transferor, make explicit mention of trust or agency funds-if, indeed, it applies to adverse claims at all.112 The drawee bank might well be reluctant to consider these generally worded sections as overruling case law and relevant provisions of the Uniform Fiduciaries Act. ${ }^{113}$

Nevertheless, the same reasons which support section 3-603 (or the proposed alternative of statutory garnishment) ${ }^{114}$ apply with equal force in the trust or agency situation. While it would be outrageous to require a bank to pay a known swindler, the fact is that the bank does not know whether the fiduciary is a swindler when he or his indorsee presents an instrument for payment. The knowledge upon which the bank's liability is predicated is knowledge of the fiduciary's motives, imputed to it by a court of law long after payment has occurred, and based upon knowledge of some of the fiduciary's acts which, if inquired into, would have given the bank reasonable grounds to suspect a misappropriation. ${ }^{115}$ Thus the real question is whether the bank should be under a duty to inquire, and to defer payment while inquiring, whether the fiduciary really has breached his duty to the true owner.

This duty of inquiry is ill-suited to banking activities. The rapidity of the collection process sharply restricts the time available to the bank for investi-

the deposit was in the name of the true owner or of the fiduciary denominated as such. Ryan Bros. v. Curwensville State Bank, 382 Pa. 248, 114 A.2d 178 (1955); Dunagan v. Bushey, supra; U.F.A. $\$ \$ 7,8$. When the deposit is in the personal account of the fiduciary, however, the bank is liable only when it has actual knowledge of a breach of duty. American Nat'1 Bank v. National Indemnity Co., 222 F.2d 513 (8th Cir. 1955); Strong v. City Nat'l Bank, 355 Pa. 390, 50 A.2d 323 (1947); U.F.A. § 9.

109. See note 26 supra.

110. See note 102 supra and accompanying text.

111. See note 107 supra and accompanying text.

1.12. See note 84 supra and accompanying text.

113. The possible conflict between Article 4 and the Uniform Fiduciaries Act has been pointed out, but no solution has been offered. Subcomarittee on the Proposed Uniforar Commercial Code, Pennsylvania Annotations 99 (1952). U.C.C. $\$ 10-102$, the specific repealer section of the Code, makes no mention of the U.F.A. However, under $\$ 10-103$, inconsistent provisions of previous acts are repealed.

114. See notes 26,38 supra and accompanying text.

115. See cases cited at note 108 supra. 
gation of possible claims, and even if unlimited time were available, the bank would still be poorly equipped to ascertain the facts and decide the questions of law involved.116 Admittedly the true owner is seldom able to detect a misappropriation until it is too late to avoid it. Nevertheless, it was the true owner who trusted the fiduciary, and it should be his responsibility to enforce that trust. The remedies available to him for preventing diversions are at once more effective and more readily utilized than those available to the bank. Bonding and countersigning requirements, for example, are the most effective methods of guarding against possible defalcations at the source. ${ }^{117}$ Moreover, the true owner may recover from parties that have given value to the fiduciary by taking his check. ${ }^{118}$ These considerations suggest that the statutory garnishment suggested as an alternative to section 3-603 should be applied to prevent constructive notice of this type of adverse claim. The bank, which acts only as a conduit, should be under a duty of care to the depositor, but not a duty of vigilance over his activities. The presumption that a fiduciary will act in conformity with his trust, ${ }^{119}$ combined with the nature of the bank collection process, should relieve the bank from liability for "knowledge" based upon suspicion or upon hypothetical inquiries which the bank is in no position to make.

\section{Article 8: Stock Transfers}

The nature of the stock transfer transaction suggests a treatment of adverse claims similar to that given claims against a drawee bank. ${ }^{120}$ The duty of a corporation to register the transfer of securities is generally delegated to

116. Kinstlinger v. Manufacturers Trust Co., 280 App. Div. 729, 734, 1.17 N.Y.S.2d 147, 151 (1st Dep't 1952) ; see text at note 29 supra.

117. Note, 25 Ill. L. Rev. 298, 302 (1930). But see Merrill, supra note 105, at 1095.

118. U.C.C. $\$ 3-30+(2)$ (b). This would also include a drawee bank of deposit which with knowledge of the trust nature of the funds set off the fiduciary's personal debt against his deposit. See note 108 supra.

119. American Security Co. v. Waggoner Nat'l Bank, 83 F.2d 99 (5th Cir. 1936) ; Citizens Bank v. Middlebrooks, 209 Ga. 330, 72 S.E.2d 298 (1952) ; Bischoff v. Yorkville Bank, 218 N.Y. 106, 111, 112 N.E. 759, 760 (1916) ; New Amsterdam Cas. Co. v. Robertson, 9 Ore. 663, 669, 278 Pac. 963, 965 (1929) ; Comment, 45 Mich. L. Rev. 78, \&6 (1946).

120. Christy \& McLean, The Transfer of Stock \$\$ 7-\$ (2d ed. 1940) (hereinafter cited as Christy \& McLEaN). All securities governed by Article 8 are negotiable under $\$ 8-105(1)$. Under the Code, as under existing law, a transfer of securities is effective as between the owner of record and the purchaser upon delivery to the latter. U.C.C. \$ 8-307; Cumningham v. Schmitz, 137 Cal. App. 2d 640, 290 P.2d 937 (1955). The issuer need not consider the transferee as owner of the security until the transferee has registered the transfer with the issuer under $\$ \$-207(1)$; but it is under a duty to register a valid transfer as an incident of the stockholder's inherent right to transfer the stock as he might any wthur property. Wentworth v. Russell State Bank, 167 Kan. 246, 205 P.2d 972 (1949); Compania de Astral, S.A. v. Boston Metals Co., 205 Md. 237, 107 A.2d 357 (1954); Christy \& McLEAN $\$ 36$. Thus the issuer, presented with a request for registration of transfer, is a true stakeholder: it admits a duty to the true owner of the security to pay dividends, recognize voting rights, and so on. U.C.C. \$\$ \&-102(1) (c), 8-207; BALLANTINE, Cokforatons 753-55 (rev. ed. 1946) ; Christy \& Mclean \$\$ 30-31. 
banking institutions designated transfer agents. ${ }^{121}$ Transfer agents deal with large numbers of registrations under circumstances which would warrant almost as automatic a rule as that sought in bank collections. ${ }^{122}$ Since securities are ordinarily purchased through stockbrokers, the incidence of holders in due course is high. ${ }^{123}$ The resulting likelihood that most adverse claims will not be successful suggests a strong need for protection against invalid claims.

Existing law has nevertheless placed the transfer agent, confronted with an adverse claim, ${ }^{124}$ in as precarious a situation as that of the payor of commercial paper. ${ }^{125} \mathrm{He}$ will be liable to the holder if registration of transfer is wrongly refused, ${ }^{126}$ and liable to the claimant if the claim proves justified after registration. ${ }^{127}$ Seldom equipped to ascertain either the validity of the claim

121. Berte \& Warren, Business Organizattons 250-51 (1948); Christy \& MIclean $\$ 279$; see Behrends \& Elliott, Responsibilities and Liabilities of the Transfer Agent and Registrar, 4 So. Calif. L. Rev. 203, 205 (1931). "Transfer agent" is used hereinafter to include the "issuer." Section 8-406 of the Code places the transfer agent under the same duties as an issuer.

122. See U.C.C. $\$ 8-314$, comment. For a description of the registration process, see Dice \& Eiteman, The Stock Market 300-01 (3d ed. 1952).

123. Texas Legislative Councti, Analyses of Article 8 of the Uniforr ConMERCTAL CODE 54 (1954); see U.C.C. § 8-204, comment 1. The transferee of a security seldom sees the old security; thus he can rarely be deemed to have had notice of claims against the security. U.C.C. $\$ \S 8-31.1$, comment 1 ; 8-314, comment 1 ; Walker, U.C.C. Article 8-Investment Securities, 14 Oнro ST. L.J. 57, 63 (1953). Moreover, brokerage firms deal with hundreds of securities daily; they seldom have the opportunity to examine their files for notices of claims which they may have received. The Code has set limits beyond which brokers are allowed to "forget" such notices and still be deemed bona fide purchasers for value. U.C.C. \$ 8-304 \& comment 3 .

124. Two types of claims are to be distinguished. The first is based on an allegation which, if true, would render the transfer nugatory. Forgery is an example. For a discussion of the Code solution to the forgery question, see Note, $103 \mathrm{U}$. PA. L. REv. 209, 21622 (1954). Another and more troublesome type of claim is one which involves a fraud or a breach of fiduciary obligation, resulting in a voidable transfer. Christy, Responsibilities in the Transfer of Stock, 72 BANking L.J. 761, 765 (1955).

125. See note 20 supra and accompanying text.

The duty placed on the corporation has been likened to one of trust. See, e.g., Lowry v. Commercial \& Farmers' Bank, 15 Fed. Cas. No. 8581, at 1047 (C.C.D. Md. 1848) ("The corporation is thus made the custodian of the shares of stock, and clothed with power sufficient to protect the rights of every one interested, from unauthorized transfers . ..."). See also Seymour v. National Biscuit Co., 107 F.2d 58, 63 (3d Cir. 1939), cert. denied, 309 U.S. 665 (1940).

126. Hertz v. Record Publishing Co., 219 F.2d 397 (3d Cir.), cert. denied, 349 U.S. 912 (1955) ; Jones v. Osage Oil \& Refining Co., 280 Fed. 696 (2d Cir. 1922); Virginia Pub. Serv. Co. v. Steindler, 166 Va. 686, 187 S.E. 353 (1936).

127. Seymour v. National Biscuit Co., 107 F.2d 58 (3d Cir. 1939), cirt. denied, $30 y$ U.S. 665 (1940); Wilson Lumber Co. v. McAllister, 101 F.2d 709 (9th Cir. 1939); Fiala v. Connecticut Elec. Serv. Co., 114 Conn. 172, 158 At1. 211 (1932); Dewey, The Transfer Agent's Dilemma: Conflicting Claims to Shares of Stock, 52 HARv. L. Rev. 553, 558-67 (1939). The transfer agent may deny registration for a "reasonable" time in order to make an investigation, but this standard has given little certainty. Note, $103 \mathrm{U}$. PA. L. REv. 209, 215 (1954); cf. note 98 supra and accompanying text. 
or the bona fides of the holder's purchase, ${ }^{128}$ transfer agents have sought to protect themselves by imposing cumbersome safeguards to establish the rightfulness of transfers. These private safeguards have slowed and complicated the procedures by which shares are registered. ${ }^{129}$

The 1955 amendments to the Code sought to answer criticism leveled at earlier drafts which had substantially incorporated the difficulties of present law. ${ }^{130}$ Section 8-403 as amended contains an adverse claim provision fundamentally similar to section 3-603. ${ }^{131}$ Upon notice of a claim to an interest in

128. See Note, 103 U. PA. L. Rev. 209, 215 (1954) ; Harper's Magazine, Jan. 1956, p. 34.

129. Christy \& McLean 7; U.C.C. \$ 8-402, comment 1 . The obstacles imposed by the transfer agent in an attempt to assure himself of the rightfulness of the transfer have also handicapped the management of trust estates. Scott, Participation in a Breach of Trust, 34 HARv. L. REv. 454, 466 (1921). Although $\S 3$ of the Uniform Fiduciaries Act relieves the transfer agent of liability unless he has actual knowledge of a breach of trust, transfer agents have not always been able to rely on this provision. See Note, 103 U. PA. L. REv. 209, 211 n.17 (1954). And because of the large number of requests for registration under circumstances which may give rise to adverse claims, a resort to interpleader would be impracticable. Dewey, supra note 127, at 577-78.

The result in practice has been to allow the claimant to provide indemnity to the transfer agent while the former obtains legal process. Christy \& MCLEAN 403. Another alternative has been insurance against improper payment. Christy, Responsibilities in the Transfer of Stock, 72 Banking L.J. 761, 762 (1955). The Code has attempted in several respects to facilitate transfer. Section 8-312 allows the transfer agent to rely upon signature guarantees, thus making it unnecessary to look into possible claims of forgery or legal incapacity. Sections $8-402(2)(a)-(\mathrm{g})$, as amended 1955 Supr., limit the evidence which the transfer agent may require to prove the rightfulness of the transfer.

130. Israels, Article 8-Iniestment Securities, 16 LAw \& Contenrp. Prob. 249, 262 (1951). For an excellent comparison of existing law with the Code in this respect, see Note, Duties and Liabilities of the Stock Transfer Agent Under the Uniform Commercial Code, 103 U. PA. L. REv. 209 (1954).

131. U.C.C. $\S 8-403$, as amended 1955 Supp., reads as follows:

"(1.) Where a security presented for registration is fully indorsed for transfer, the issuer is under no duty to inquire into the rightfulness of the transfer unless he has notice of another claim to an interest in the security. In such event he may discharge the duty of inquiry by any reasonable means, including notifying the adverse claimant by registered mail ... that the security has been presented for registration of transfer by a named person, and that such transfer will be registered unless within fourteen days... the claimant either

(a) procures an appropriate restraining order, injunction or other process from a court of competent jurisdiction in a cause therein instituted by the claimant wherein the person who has presented the security for registration of transfer is made a party and served with summons; or

(b) files with the issuer an indemnity bond sufficient to protect the [transfer agent] ... from any loss which it or they may suffer by complying with such adverse claim.

"(2) The fact that the issuer has notice that the security is held for a third person or is registered in the name of or indorsed by a fiduciary does not create a duty of inquiry into the rightfulness of the transfer. If, however, the issuer has notice 
the security, ${ }^{132}$ the transfer agent is under a duty to inform the claimant when the security is presented for registration. ${ }^{133}$ The claimant is allowed two weeks after notification to take legal action against the holder or to indemnify the transfer agent against harm resulting from continued refusal to register. ${ }^{134}$ The new section is, however, open to the objections which have been made against section 3-603. ${ }^{135}$ Logical extension of the presumptions afforded the holder requires that he be entitled to registration of transfer unless the adverse claimant undertakes to prove his claim in court, yet the indemnity feature of section 8-403 places upon the holder the burden of initiating litigation.

The statutory garnishment previously proposed ${ }^{136}$ could not be utilized in the stock transfer situation, since the stakeholder's duty is one of service rather than payment; there are no proceeds to garnishee until presentment. The most feasible alternative would be a temporary injunction against the transfer agent requiring him to notify the claimant at presentment and restraining registration on condition that the claimant bring suit within twenty-four hours. This is swifter than, but generally equivalent to, the injunction provision in section 8-403. The indemnity provision should be eliminated, ${ }^{137}$ since, in a context where bona fide purchasers are commonly found ${ }^{138}$ and are given a high degree of protection, ${ }^{139}$ the burden of bringing suit should be on the claimant.

A further criticism of the Code provision is that the transfer agent may be

that . . the transaction is for the individual benefit of the fiduciary, the issuer is under a duty to inquire into the rightfulness of the transfer."

Compare CAL. CORP. CODE ANN. $\$ 2410$ (1953), under which the corporation may transfer the stock on its books unless the claimant (1) gives written notice of his claim; (2) provides indemnity within five days after notice; and (3) begins an action within sixty days after giving notice of his claim.

132. It is not clear what kinds of claims fall within the meaning of "claim to an interest in the security." Resort to prior law would be necessary to determine exactly what claims are encompassed. It seems likely that insufficiency of consideration, breaches of pooling or option agreements, and certain types of fraud will not be held to be included. Note, 103 U. PA. L. REv. 209, 222-27 (1954). If adverse claims are to be given recognition at all, however, and if the danger which uncertainty creates to the transfer agent is to be removed, these claims, which are disputes between the parties going to the validity of the underlying transaction, should also be included.

133. Failure to do so will result in the liability of the issuer to deliver a like security to the claimant if the claim is substantiated. U.C.C. \& 8-404.

134. Under $\$ 8-401$ the transfer agent must register the transfer and would presumably be liable for a wrongful refusal to transfer. See $\$ \$ 8-401$, comment $1 ; 8-406$, comments 1,3 . However, the transfer agent is under no obligation to register if he has notice of an adverse claim by the provisions of $\S 8-401$ (1) (b). Therefore, the Code may be construed to prevent liability for refusal to transfer upon notice of an adverse claim, even without an indemnity bond, at least for a two-week period.

135. See text at notes 30-37 supra.

136. See note 38 stipra and accompanying text.

137. Cf. Ontario Corporattons Act c. 19, § 50 (1953).

138. See note 123 supra and accompanying text.

139. Walker, supra note 123, at 58-59; Israels, supra note 130, at 252. 
given constructive notice of an adverse claim. Section 8-403(2) subjects the transfer agent to a duty of inquiry upon actual or constructive notice of a breach of trust. He would therefore be liable for failing to send notice to a potential adverse claimant whenever, in retrospect, the surrounding circumstances can be used to impute knowledge to him. ${ }^{140}$ Moreover, it is not clear whether the transfer agent could discharge a duty of inquiry thus arising, even if he knew it existed, by informing the beneficiary of presentment and requiring indemnity or legal process under the provisions of subsection 8-403(1). It is possible that he must actually make the type of investigation deemed impracticable for payors of commercial paper. ${ }^{141}$ But a similar result should obtain whether or not the adverse claim is based on an alleged breach of trust. Fiduciaries ordinarily are faithful to their duties, ${ }^{142}$ and beneficiaries of trusts can be better protected by other and more efficient means. ${ }^{143}$ Therefore, whether a trust is involved or not, the registration of transfer should be automatic unless an adverse claimant takes affirmative action to protect his right to sue on his claim.

\section{Article 5: Documentary Letters of Credit}

A documentary letter of credit is a promise made by a bank to a seller of goods on behalf of the buyer. ${ }^{144}$ The promise provides that the bank will pay

Under $\$ S-301(2)$ the bona fide purchaser receives a perfect title to the security; he takes free of adverse claims under $\$ \$-315(1)$, as well as claims of forgery under $\$ 8-311$, if he has received a new registered security. See also $\$ \S 8-202(1)$ (restrictions not on security), 8-202(4) (defense of nondelivery or conditional delivery), 8-205 (issuer may be estopped from asserting forgery) and S-206 (altered or fraudulently completed security).

140. See note 131 supra. Constructive notice is included within the meaning of "notice" under U.C.C. $\$ 1-201$ (25) (c). For a discussion of constructive notice under existing law, see Hazzard v. Chase Nat'l Bank, 159 Misc. 57, 74, 287 N.Y. Supp. 541, 559 (Sup. Ct. 1936). Compare U.F.A. $\$ 3$ which limits the transfer agent's liability to cases of registration in bad faith.

141. Under a similarly phrased adverse claim statute to bank deposits, beneficiaries of trusts are not required to provide indemnity or to obtain legal process. See note 100 supra and accompanying text.

142. Israels, supra note 130 , at 265 . See note 119 supra and accompanying text.

143. Bunn, Article 8-A Law for the Transfer of Investment Securities, 1952 Wrs. L. REv. 339, 346. See notes 117-18 supra and accompanying text. The beneficiary's rights against purchasers are set forth in \$ \$-304(2), which charges a purchaser with notice of a breach of trust if value for a security held in trust is given in cash or otherwise to the fiduciary individually. U.C.C. \$ \$-315(1) allows a claimant to reclaim possession of the security against the holder if the transfer was wrongful, unless the latter is a bona fide purchaser for value. Subsection (3) provides for an injunction against further transfer, or, if possible, impounding of the security.

144. See Gilmore, The Commercial Doctrine of Good Faith Purchase, 63 Yale L.J. 1057, 1108-09 (1954). Typical credit forms are set out in BRAUCHER, SUTHERLAND \& WIILCox, Conkmerctal Transactions 196-207 (1953). For discussions of variants of the basic yattern of the letter of credit, see Ward \& Harfield, Bank CRedits and Acceptances 10-17 (3d ed. 1948) (hereinafter referred to as Wakd \& HarfIELD); McCurdy, Commer- 
the purchase price of the sale by honoring drafts drawn upon it by the seller on condition that the drafts be accompanied by specified shipping documents which indicate that the seller has delivered the goods for which the buyer bargained. ${ }^{145}$ Generally accepted case law and thought treat the letter of credit as a transaction of documents, not of goods: the underlying sales contract is theoretically not in issue. ${ }^{146}$ The adverse claim situation demonstrates, however, that the documents are the connecting link between the sales contract and the credit, and that in practice the two cannot be completely divorced. ${ }^{1.47}$ Thus, the claim against the right of the holder to payment generally arises as a buyer-seller dispute: the buyer will order the bank not to pay drafts issued under the credit when he believes that the documents demonstrate the seller's breach of the underlying sales contract. The buyer's contentions may be in

cial Letters of Credit, 35 HARv. L. REv. 539, 542-43 (1922). For a brief history of the letter of credit, see Trimble, The Law Merchant and the Letter of Credit, 61 HaRv. L. Rev. 981 (1948).

The letter of credit has major commercial advantages. One is that banks offer the service at a rate of about $1 / 3$ of $1 \%$ of the face value of the credit. Harfield, Article 5-Trade Without Tears, 1952 Wrs. L. Rev. 298, 299-300. Another is that the seller can rely on the promise of a bank rather than that of a buyer. This advantage is particularly significant when the bank's promise is irrevocable, as is generally the case in commercial transactions. U.C.C. $\$ 5-105$ provides that a credit is revocable unless otherwise stated. Even if revocable, however, the credit may not be changed or cancelled after it has been honored or drafts have been negotiated under it. U.C.C. $\$ 5-106(2)$ (c). In the following discussion it is assumed that an irrevocable credit has been issued by a bank, or that if a revocable credit was involved it has subsequently been sealed by honor or negotiation.

145. The documents required may vary with each credit, but usually include sellers' invoices, bills of lading, and, in international transactions, consular invoices and weight and insurance certificates. See, e.g., North Woods Paper Mills, Ltd. v. National City Bank, 121 N.Y.S.2d 543 (Sup. Ct. 1953).

146. U.C.C. § 5-102(1); Ward \& Harfietd 7; International Chaniber of Conarerce, Uniform Custonis and Practice for Comarerctal Docunientary Crebits art. 10 (rev. ed. 1951) (hereinafter referred to as ICC Custons). Thus the bank is excused from honoring the draft only when the documents fail to conform to the terms of the credit. U.C.C. \$ 5-107(1) ; Banco Nacional v. Bank of America, 11S F. Supp. 308, 310 (N.D. Cal. 1954); Bank of East Asia, Ltd. v. Pang, 140 Wash. 603, 249 Pac. 1060 (1926). For the transaction is solely between the issuing bank and the seller or holder of the draft; if the buyer has a defense on the underlying sales contract, his remedy must be asserted directly against the seller. American Steel Co. v. Irving Nat'l Bank, 266 Fed. 41 (2d Cir. 1920), cert. denied, 258 U.S. 617 (1922) ; Grob v. Manufacturers Trust Co., 177 MIisc. 45, 29 N.Y.S.2d 916 (Sup. Ct. 1941) ; Consolidated Sales Co. v. Bank of Hampton Roads, 193 Va. 307, 68 S.E.2d 652 (1952). But see Société Métallurgique v. British Bank for Foreign Trade, 11 Lloyd's List L.R. 168, 170 (K.B. 1922). In addition, the issuing bank may not raise as a defense to the draft any claim or defense it would have vis-à-vis the buyer. $C f$. Asbury Park \& Ocean Grove Bank v. National City Bank, 35 N.Y.S.2d 985, 989 (Sup. C.. 1942).

147. See Asbury Park \& Ocean Grove Bank v. National City Bank, supra note 146, at 989; Finkelstein, Legal Aspects of Commerrctal Letters of Credit 223-24 (1930) (hereinafter refered to as Finkelstern); McCürdy, supra note 144, at 724; notes 157-59 infra. 
sood faith, but may often reflect an attempt to avoid the consequences of a falling market. ${ }^{148}$

The contemplated extension of the letter of credit form to domestic commerce will often bring a new party into the dispute. Today, the bank issuing a letter of credit generally is indifferent to the sales contract; the bank is used primarily to facilitate the mechanics of large-scale international dealings. ${ }^{149}$ But the domestic letter of credit, ${ }^{150}$ in addition to assuring the seller of payment, ${ }^{151}$ will also be more frequently used to finance the buyer's end of the sales transaction: the issuing bank will retain a security interest in the underlying goods. ${ }^{152}$ Thus the buyer's claim that the goods are defective

148. See, e.g., Maurice O'Meara Co. v. National Park Bank, 239 N.Y. 386, 146 N.E. 636 (1925); Finkelstexn 231; Note, 65 HARv. L. Rev. 1420, 1424 (1952). The bulk of letter of credit litigation arose after the break in the sugar market following the end of World War I. See, c.g., Moss v. Old Colony Trust Co., 246 Mass. 139, 140 N.E. 803 (1923). Absent a price break, the buyer will generally accept indemnity against apparent nonconformity between the documents and credit rather than attempt to avoid the entire transaction. See Dixon, Irmaos \& Cie, Ltda. v. Chase Nat'l Bank, 144 F.2d 759 (2d Cir. 1944), iert. denied, 324 U.S. 850 (1945).

149. See U.C.C. \$ 5-111, comment 2. Nine-tenths of international sales transactions are financed by letters of credit. Note, 65 HARv. L. Rev. 1420 n.2 (1952). Approximately twenty-five banks in the United States handle over $75 \%$ of the volume of credit transactions. Chadsey, Practical Effect of the Uniform Commercial Code on Documentary Letter of Credit Transactions, 102 U. PA. L. REv. 618, 620 (1954).

150. Prior to the war, the letter of credit had very limited use in domestic commerce. See Chadsey, supra note 149, at 620 ; Harfield, supra note 144, at 302; note 149 supra. A1though domestic letters of credit are still in an experimental stage, the postwar period has witnessed a substantial increase of the credit form in many phases of domestic commerce. Dougan \& Calkins, Doctmentary Letters of Credit, 15 Ouro ST. L.J. 33 (1954) ; Gilmore, Chattel Security: II, 57 YaLE L.J. 761, 765 (1948). For examples of some instances in which letters of credit have seen use in domestic transactions, see Consolidated Sales Co. v. Bank of Hampton Roads, 193 Va. 307, 68 S.E.2d 652 (1952) (electrical appliance financing); McGowan, Trust Receipts 14, 15 (1947).

151. See Block v. Pennsylvania Exchange Bank, 253 N.Y. 227, 230-32, 170 N.E. 900, 901 (1930); note 144 supra. The assurance of payment under the credit has special significance in so far as it enables the seller to discount the draft as soon as the goods are shipped or the draft is accepted, and thereby finance his enterprise. Maurice O'Meara Co. v. National Park Bank, 239 N.Y. 386, 397, 146 N.E. 636, 639 (1925) ; Ward \& HARFIELd 25-26.

152. FinKELSTEIN 230.

The usual procedure is for the buyer to provide collateral security guaranteeing reimbursement to the issuing bank before the credit is issued. The issuing bank then requests reimbursement one day before payment of a draft it has accepted. This practice is codified in U.C.C. \& 5-107(2). If the draft is a time draft, the buyer is given the time between acceptance and payment in which to raise the proceeds for reimbursement.

The buyer frequently pledges the goods bargained for as security for reimbursement. The documents then arrive made out to the order of the issuing bank; as long as the bank retains control over the documents, the letter of credit is, in a sense, self-securing. The bank may also release the documents to the buyer in exchange for trust receipts to insure its loan; the buyer then sells the goods, using the proceeds to pay its debt to the bank. See, c.g., Gidden v. Chase Nat'1 Bank, 82 N.Y.S.2d 341, 342 (Sup. Ct. 1948). This procedure seems to be gaining favor as a method of floor-financing. See, e.g., Consolidated Sales Co. v. Bank of Hampton Roads, 193 Va. 307, 68 S.E.2d 652 (1952). 
will provide the bank with strong motives for resisting payment to the holder. Even when it has no security interest in the goods, the bank's decision may also be influenced by "outside" considerations. Where the bank is primarily concerned with preserving its credit standing with confrming or negotiating banks, it may be more inclined to pay. ${ }^{153}$ Especially in domestic commerce. however, the buyer may be a regular customer of the issuing bank: ${ }^{154}$ his dissatisfaction with the sales contract may put the bank under considerable ecnnomic pressure to refuse payment. ${ }^{155}$ Conversely, the bank may have been selected by the seller, who may exert a similar type of pressure to compel payment. ${ }^{150}$

Commercial policy dictates that when a draft has been issued or accepted pursuant to the terms of the credit, the interests of both the buyer and the issuing bank should be subordinated to the interests of the seller and the holder presenting the draft. ${ }^{157}$ The letter of credit is primarily a seller's device, intended to insure the seller against the insolvency of an unknown buyer and

153. In international commerce, the issuing bank has usually obtained collateral security from the buyer to assure it of reimbursement. With no security interest in the goods immediately involved, the issuing bank will seek to pay the instrument rather than lose it: credit rating with other banks which have discounted the seller's draft. FrNkELSTEIN 219: U.C.C. \$ 5-111, comment 2. But cf. Trimble, supra note 144, at 1008 .

154. A buyer in need of credit will ordinarily have to deal with his local bank rather than a large metropolitan bank. Generally, the buyer arranges it so that the local bank: obtains a letter of credit in his favor from a large bank. See, e.g., Asbury Park \& Ocean Grove Bank v. National City Bank, 35 N.Y.S.2d 985 (Sup. Ct. 1942). Under the Code it is also possible for the local bank to issue the credit directly, with the large bank "confirming" it (i.e., adding its irrevocable promise to that of the local bank). U.C.C. \$ 5-103, comment 4. For existing confirmation practice, see WARD \& HARFIELD 25, 28-29.

155. Id. at 150; Comment, 63 Harv. L. Rev. 1373, 1377 (1950). The issuing bank generally notifies the buyer when the draft arrives for payment or acceptance; the buyer may then raise any objections he has to payment. It has been suggested that the bank may even be under an obligation to consult with the customer before payment. Comment, 62 Y ALE L.J. 227, 249 (1953).

156. WARD \& HARFIELD 59; see note 153 supra and accompanying text.

157. See Continental Nat'l Bank v. National City Bank, 69 F.2d 312, 316 (9th Cir.), cert. denied, 293 U.S. 557 (1934) ; Frey \& Son, Inc. v. Sherburne Co., 193 App. Div. 449. 854, 184 N.Y. Supp. 661, 664 (1st Dep't 1920) ; Chadsey, stura note 149, at 624; Harficld, supra note 144, at 309; Comment, 63 Harv. L. REv. 1373, 1377 (1950); Note, 55 Harv. L. REv. 878, 880 (1942). But see Campbell, Guaranties and the Suretyship Phases of Letters of Credit, 85 U. PA. L. REv. 175, 260, 272 (1936). The contrast between the commercial need to protect the seller and the interest of the bank in protecting its security interest is perhaps best brought out in the majority and minority opinions of the New York Court of Appeals in Maurice O'Meara Co. v. National Park Bank, 239 N.Y. 386, 401, 146 N.E. 636. 641 (1925).

Although the bank with a security interest would have an interest in ascertaining the conformity of the goods, the requirement that it act only on the face of the documents is, in the long run, to the bank's advantage. A contrary rule would inevitably involve the bank: in technical disputes over the quality of the goods, forcing it into inquiries which it is seldom equipped to make. Kingdom of Sweden v. New York Trust Co., 197 Misc. 431, 450, 96 N.Y.S.2d 779, 795 (Sup. Ct. 1949) ; Note, 29 ILL. L. REv. 806, 809 (1935). 
to guarantee prompt and sure payment. ${ }^{158}$ In order to finance his enterprise, the seller will probably discount the draft at his bank, which, having relied on the credit, will present the draft to the issuing bank for payment. ${ }^{159}$ If the letter of credit form is to attain any degree of significance in domestic commerce, the discounting bank, which has almost invariably acted in good faith, ${ }^{\mathbf{1 6}}$ must be protected. The efficacy of the documentary letter of credit as a means of financing domestic transactions depends on the confidence with which holders may rely solely on the terms of the credit and the documents involved. ${ }^{101}$

The Code provisions fail to effectuate these policies sufficiently. Section $5-111(1)^{162}$ recognizes the importance of free negotiability in the letter of credit context, and places the burden of litigation on the buyer. He may prevent payment only by procuring an injunction based upon allegations of

158. See Hibernia Bank \& Trust Co. v. J. Aron \& Co., 134 Misc. 18, 22, 233 N.Y. Supp. 486, 490-91. (Sup. Ct. 1928) ; authorities cited note 151 supro.

159. The seller may need funds immediately, and so will often discount the draft rather than present it himself for payment. See note 151 supra. The letter of credit may be for "acceptance," the issuing bank accepting the draft upon presentment of the documents. Before acceptance, of course, every holder bears the risk that the documents may not conform to the terms of the credit. After acceptance, however, the draft becomes "prime" paper which the seller can more easily discount. See Dougan \& Calkins, supra note 150, at 34. Theoretically, neither buyer nor bank may then challenge the sufficiency of the documents, but buyer may attempt to stop payment by alleging that the goods are so different from the description in the documents that fraud may be inferred. See notes 148 supra, 161, 171 infra.

160. WARD \& HaRfIELD 22-24.

161. Correcting adverse claims defects will accomplish little if the Code allows the buyer to sustain his claims indirectly by asserting a technical nonconformity of the documents to the highly detailed terms of the credit. It is almost always possible to find technical defects in the documents presented with the draft; when the market has fallen, the buyer, and often the bank if it has retained a security interest in the goods, will be anxious to assert these irregularities. See note 148 supra. The Code provides, however, that the issuing bank is not necessarily under an obligation to accept an offer of indemnity against harm resulting from even technical nonconformity of the documents; it leaves the problem largely to banking custom. U.C.C. $\$ \$ 5-102,5-113$. This indefiniteness is the result of the draftsmen's views that a too elaborate set of rules might freeze commercial development, or, more likely, would rapidly become obsolete. Dougan \& Calkins, supra note 150 , at 40 . See also Gilmore, On the Difficulties of Codifying Commercial Law, 57 YALE L.J. 1341, 1356-59 (1948) ; MLass v. Old Colony Trust Co., 246 Mass. 139, 151, 140 N.E. 803, 807 (1923). But sec Comment, 62 YALE L.J. 227, 262 (1953) (pointing out the need for more ascertainable criteria).

162. "Unless otherwise agreed

(1) A bank which has issued or confirmed a credit is not excused from honor or reimbursement by the fact that the goods or documents do not conform to the underlying contract for sale ... ; but in the event of forgery or fraud in a required document, a court of appropriate jurisdiction may enjoin the issuing or confirming bank from honoring or reimbursing unless such honor or reimbursement is demanded by a paying, accepting, or confirming bank which has acted in good faith in reliance on the document or by a negotiating bank or other endorsee of a draft which is a holder in due course and acts under a credit extending by its terms to a negotiating bank or endorsee." U.C.C. \$ 5-111(1). 
fraud ${ }^{163}$ or forgery ${ }^{164}$ in the documents. Moreover, even then the injunction may not pre-empt the rights of a holder in due course. ${ }^{165}$ Section 5-111(2), ${ }^{1011}$ however, substantially offsets this result by allowing the issuing bank, in its discretion, to refuse payment and set up the buyer's claim of fraud or forgery as a defense. The holder in due course may eventually prevail, ${ }^{167}$ but will be forced to assume the burden of litigation; and he may be obliged, as a practical matter, to resell the goods in the interim. ${ }^{168}$ The section therefore permits a result counter to the essential purposes of the letter of credit: the buyer, with the co-operation of the issuing bank, may gain important tactical advantages without proving the validity of his claims. ${ }^{169}$

In order to prevent both buyer and issuing bank from defeating the very purposes for which the letter of credit was devised, the issuer should be obliged

163. The Code distinction between nonconformity of the goods to the documents and fraud in the documents, see note 162 supra, will be difficult to enforce in practice. It is stated that nonconformity of the goods is no defense to payment. U.C.C. $\$ 5-111$, comment 1; see Bank of East Asia, Ltd. v. Pang, 140 Wash. 603, 249 Pac. 1060 (1926). Nevertheless, in most instances the buyer's only method of establishing a prima facie case of fraud "in the documents" will be to show a discrepancy between the goods and documents sufficient to allow an inference of fraud. FinkeLstein 230; Bank of Montreal v. Recknagel, 109 N.Y. 482,17 N.E. 217 (1888) ; see U.C.C. \$ 4-116 (May 1949). But the Code offers no guides to determine what amount of nonconformity constitute's fraud. Thus the courts will have to consider the circumstances of each case to distinguish contract defenses from fraud. Dougan \& Calkins, supra note 150, at 41; Comment, 62 YALE L.J. 227, 254 (1953). See Société Métallurgique v. British Bank for Foreign Trade, 11 Lloyd's List L.R. 168 (K.B. 1922).

164. The Code, following the weight of recent authority, has adopted the view that the risk of forged documents is on the buyer; the buyer cannot pass the risk of loss on to the bank, for paying or negotiating banks do not warrant the gentineness of the documents. U.C.C. $\$ \$ 5-110(1), 5-111$; see Ward \& Harfierd 54-55, 97. But sce Davis, Commercial LeTters of CREDIT 155-66 (2d ed. 1954); Finketstetn 239. Where the draft itself is forged, however, the issuing bank assumes the risk of loss. McCurdy, stpra note 144, at 735.

165. The Code follows existing law in refusing to permit an injunction against a holder in due course. See Maitland v. Chartered Mercantile Bank, 38 L.J.R. 363 (Ch. 1869); FiNKELSTEIN 171-72.

166. "(2) Whether or not the issuing or confirming bank is notified of . . an alleged forgery or fraud in a document apparently regular on its face, such bank, unless enjoined, may nevertheless honor or reimburse and, in turn, it shall be entitled to recover reimbursement from the person obligated to reimburse it." U.C.C. \$ 5-111(2). (Emphasis added.)

167. It is presumed that the protection given the good faith purchaser by $\$ 5-111(1)$, see note 162 supra, will be incorporated into $\$ 5-111(2)$, so that the issuing bank will not be able to sustain its defense of fraud or forgery. See Sub-Committee Report, 1955 Surr. 155-56. This result obtains under existing law. Bank of Taiwan v. Union Nat'l Bank, 1 F.2d 65, 66 (3d Cir. 1924).

168. Section 5-116(1) also gives the holder who is not the seller all the rights of a seller similarly situated. See Comment, 62 YALE L.J. 227, 257-58 (1953).

169. See WARD \& HaRFIELD 35.

The advantage of being sued rather than suing gains special importance in the letter of credit situation. In addition to the ordinary procedural and jurisdictional advantages, the buyer would have greater time and opportunity to select the grounds on which he will 
to pay the holder unless the buyer has either obtained an injunction under provisions similar to section 3-603 or procured a statutory writ of garnishment pending an action against the holder. ${ }^{170}$ Bank and buyer may, of course, be able to protect themselves by inserting safeguards in the terms of the credit. ${ }^{171}$ But once a holder has acted in good faith reliance on the terms stated, he should be given the substantive and the procedural advantage against the buyer and the issuing bank.

\section{Article 7: Negotiable Documents of Title}

A negotiable bill of lading or warehouse receipt is a document of title, issued by a bailee upon deposit of goods with him, in which he unqualifiedly promises to deliver the goods to the holder of the document. ${ }^{172}$ The dual nature of these documents is a characteristic which permeates not only their negotiation, but also the method by which the law resolves problems involving adverse claims to them and the goods they represent. For the documents, besides being symbols of the underlying goods, are also negotiable instruments which play an important role in credit finance. ${ }^{173}$ And in the latter context property rights

defend than if, as under the garnishment procedure previously discussed, he were required to specify, at the time when he demands that payment be stopped, the defects in the documents which he plans to attack. See note 38 sipra.

170. See notes 26,38 supra.

171. This procedure, however, has two limitations. First, the letter of credit has gained acceptance mainly because of the simplicity with which it enables international transactions to be handled, and thus should not be hampered by too many conditions. WARD \& HARFIELD 3, 20, 34; Note, 65 Harv. L. REv. 1420, 1423 (1952). Secondly, a fraudulently inclined seller will attempt to make the documents conform as much as possible to the terms of the credit. Thus the protection does not extend to the most objectionable types of fraud, a risk which must eventually be borne by the buyer. FrNkessiers 216-18; Llewcllyn, Some Advantages of Letters of Credit, 2 J. Business 1, 9-10 (1929); Note, 9 WASE. I. REv. 159, 161 (1934).

172. Article 7 replaces the Uniforar Warenouse Recerpts Act (hereinafter cited as U.W.R.A.), promulgated in 1906 and adopted by all jurisdictions, and the UNmroRur Burs of LAding ACT (hereinafter cited as U.B.L.A.), promulgated in 1909 and enaeted in 35 jurisdictions. Article 7 is superseded by applicable federal law. U.C.C. § 7-103. Sce United States Warehouse Act, 39 STAT. 486-91 (1916), as amended, 7 U.S.C. $\$$ 241-73 (1952); Federal Bills of Lading Act, 39 Stat. 538-45 (1916), 49 U.S.C. \$§ 81-124 (1952). For brief historical surveys of legislation concerning documents of title, see Blomquist, Warehouse Regulation since Mumn v. Illinois, 29 CEI.-KENT L. REv. 120 (1951) ; Braden, The Story of the Bill of Lading, 18 I.C.C. Prac. J. 810 (1951).

Typical warehouse receipt and bill of lading forms are set out in Braucrer, Sutrazland \& Wilicox, Comarerctal Transactrons 172-91 (1953). The term "bailce" is used to include both a warehouseman, defined in $\S 7-102(1)(h)$, and a carricr issuing a bill of lading. U.C.C. \& 7-102(1) (a). Under \$ 7-104 documents of title may be made negotiable if the bailee promises to deliver the goods to bearer, or to the order of a named person; otherwise the document is nonnegotiable.

173. Ferson, Fraudulent Bills of Lading, 21 Mirce. L. Rev. 655, 656 (1923); Scott, The Railroad Bill of Lading, 14 I.C.C. PrAc. J. 288, 292-94 (1947).

Over $90 \%$ of the loans made on merchantable commoditics are secured by outstanding documents of title. Britton, Negotiable Documents of Tille, 5 Hastracs L.J. 103, 111 
must often take second place to commercial necessity and to the risks that inhere in negotiability. ${ }^{174}$

The rights of adverse claimants under Article 7 of the Commercial Code depend upon whether their claims are based on an interest in the document: or in the goods. If the claimant can establish that the original bailment of the goods was wrongful as to him, he is deemed to be "true" owner of the goods. And since the Code, following existing law, treats the documents in this context primarily as symbols of the goods, ${ }^{175}$ the true owner's title to the goods is paramount to the holder's right to the documents regardless of the holder's good faith purchase. ${ }^{176}$ A second type of adverse claim, however, relates to defects arising after a valid bailment; the claimant contends that the documents were properly issued or negotiated to him, but were not properly negotiated by him, so that his rights in the documents were never cut off. ${ }^{177}$ The

(1954). Largely because of the legislation regulating the duties of bailees, banks are afforded certainty that loans given on the documents are actually secured by the underlying: goods. State v. Frost, 91 N.H. 229, 17 A.2d 441, 443 (1941). As a result banks may discount drafts accompanying documents of title at rates of $1 / 8$ to $1 / 2 \%$ of the face value of the drafts. Britton, supra, at 107. Documents of title are less frequently made negotiable when used as collateral for bank loans than when they are used in contracts for the sale and resale of the underlying goods. Banks prefer to prevent the possibility of having their security interest defeated by negotiation to a bona fide purchaser. Id. at 108-09, 111; see note 179 infra; e.g., Star Transfer Line v. General Exporting Co., 308 Mich. 86, 13 N.W.2d 217 (1944).

174. See Brock v. Atteberry, 153 La. 649, 96 So. 505 (1923); Lundy v. Greenville Bank \& Trust Co., 179 Miss. 282, 174 So. 802 (1937) ; Mason v. Exporters \& Traders Compress Co., 94 S.W.2d 758, 760 (Tex. Civ. App. 1936) ; U.C.C. \$ 7-501, comment 1; Texas Legislative Council, Analyses of Article 7 of the Uniform Comamercial Cone. 141-42 (1952). Of course, the need to protect the claimant is still important, not only from the point of view of promoting honesty, but also from a commercial standpoint; if banks are to advance credit on documents of title, they must have a fair opportunity to protect their intere'sts. Braucher, Docunents of Title 94-95 (1955) ; Blomquist, supra note 172, at 130 ; Braden, supra note 172 , at 819 .

175. U.C.C. $\$ 7-503(1)$ \& comment.

176. Lineburger Bros., Inc. v. Hodge, 212 Miss. 204, 54 So. $2 d 268$ (1951) ; 2 WillisTON, SALES $\$ 421$ (rev. ed. 1948) (collecting citations).

The true owner may, however, be estopped from asserting his claim against a good faith purchaser if the owner has entrusted the party who wrongfully bailed the goods. Swift v. Davis, 118 Misc. 205, 193 N.Y. Supp. 848 (Sup. Ct. 1922) ; Commercial Bank v. Canal-Louisiana Bank, 239 U.S. 520, 524-25 (1916) (dictum). See also Boswell Co. v. Felder \& Co., 103 Cal. App. 2d 767, 230 P.2d 386 (1951) ; Rotterman v. General Mills, Inc., 245 Iowa 229,61 N.W.2d 718 (1953); U.C.C. $\$ 7-503(1)$. But sec $\$ 7-502$ (1) (c) (1955 SUPP.).

177. See, e.g., Tom Boy Stores, Inc. v. Douglas-Guardian Warehouse Corp., 237 Mo. App. 892, 179 S.W.2d 145 (1944).

Claims may also arise out of a sales contract. The buyer may have paid for the goud: but allowed the seller to retain possession of the documents; or the seller may havs delivered the document of title to the buyer, retaining a security interest in the goods. See, e.g., Garrett Freight Lines v. Cornwall, 120 Utah 175, 232 P.2d 786 (1951) ; Williston, Ownership of Goods Shipped under a Bill of Lading to the Seller's Oider, \$2 U. PA. L. Rev. 1, 3 (1933). When the seller has discounted a draft on the buyer, the bank will assert 
policy considerations have shifted: the claimant, having authorized or used this form of commercial arrangement, may more equitably be subjected to the requisites of commercial expediency. ${ }^{178}$ The Code therefore adopts the holder in due course theory in this context and provides that a holder who has subsequently received the documents through "due negotiation" prevails over former holders. ${ }^{170}$ The claimant must not only sustain the validity of his claim, but must also show that the present holder is not a holder in due course who took free of claims. ${ }^{180}$

The fact that the documents represent goods in commerce injects unique considerations into the treatment of adverse claims to documents of title. The holder of the document may be a merchant who has contracted to resell the goods; unless he receives the goods immediately, he will often be unable to find substitute goods in time to fulfill his other contractual obligations. ${ }^{181}$ Even though title may not in fact be his, and he may have to reimburse the true owner, the holder might nevertheless prefer to supply indemnity and receive the goods, thus mitigating his own costs on the resale contract. On the other hand, the true owner or a prior holder claiming an interest in the documents might also have a contract to resell. ${ }^{182}$ Where contracts over are not present, interpleader would afford the best remedy. ${ }^{183}$ But when they are involved, compulsory interpleader could cause harmful delay. ${ }^{184}$ The goods would be frozen in a court's registry while the claim was being litigated unless the parties could agree to sell the goods and substitute money for the res. ${ }^{185}$ Similar objections obtain to a provision based upon section $3-603,{ }^{186}$ under

the seller's rights. Gilmore \& Axelrod, Chattel Security: I, 57 YALE I.J. 517, 524-27 (1948).

178. See note 174 supra and accompanying text.

179. U.C.C. $\$ 7-502$. See Britton, Negotiable Documents of Title, 5 Hastrngs L.J. $103,115-16$ (1954). "Due negotiation" is the purchase of a document of title made in "observance of reasonable commercial standards," on the theory that negotiable documents of title are not intended for use in noncommercial settings. U.C.C. $\$ \S 7-501(4) ; 7-503$, comment. See also U.B.L.A. $\$ \$ 38,39$; U.W.R.A. $\$ \$ 47,48$; case's cited note 174 supra.

1S0. U.C.C. $\$ 7-502(2)$.

181. See, e.g., Stitzel-Weller Distillery, Inc. v. Norman, 39 F. Supp. 182, 187 (W.D. Ky. 1941) (warehouse receipts broker). In addition, the exigencies of a rapidly fluctuating market militate against a delay in delivery. See, e.g., Behn v. Southern Pac. Co., 2 Ill. App. 2d 62, 118 N.E.2d 625 (1954) (25\% drop in market in four days) ; Railway Express Agency v. Smith, 116 F. Supp. 609 (E.D.S.C. 1953) (perishables).

182. The "true owner," however, has less frequently engaged to sell the goods. He is usually a landlord, mortgagee or conditional seller who is more interested in the proceeds than in the goods themselves. See Braucher, In Re Article 7, 28 TEMP. L.Q. 564, 581 (1955).

183. See note 25 supra and accompanying text.

184. See note 181 supra and accompanying text. Interpleader would also be undesirable if the value of the goods in dispute were too low to justify the storage charges incurred, or if the goods were perishable. Braucher, Docunrents of Title 40 (1955).

185. See, e.g., In $r e$ Taub, 7 F.2d 447 (2d Cir. 1925); Braucher, Documents of Title 40-41 (1955).

186. See note 26 supra and accompanying tesist. 
which the adverse claimant could prevent delivery to the holder, or obtain delivery himself, by providing indemnity; the holder, who might have the greater need for immediate performance, would be seriously handicapped.

Section 7-603 of the Code meets the need for flexibility by giving the bailee a limited discretion upon notice of an adverse claim. ${ }^{187}$ The section is the result of historical evolution tempered by practice. The bailee originally was denied interpleader, primarily on grounds of privity or independent liability. ${ }^{188}$ Since he was thus forced to pay at his peril,189 the law allowed him a "reasonable time" to essay a correct determination. 190 In actual practice, the bailee soon began to protect himself by delivering the goods only when he received the document of title or when a "true" owner supplied him with indemnity. ${ }^{191}$ The Uniform Bills of Lading and Warehouse Receipt Acts eliminated the restrictions on interpleader, ${ }^{192}$ but nevertheless retained the reasonable time provision. The Code follows the uniform acts in this respect. ${ }^{103}$ The

187. "If more than one person claims title or possession of the goods, the bailee is excused from delivering until he has had a reasonable time to ascertain the validity of the adverse claims or to bring an action to compel all claimants to interplead and may compel such interpleader, either in defending an action for non-delivery of the goods, or by original action, whichever is appropriate." U.C.C. $\$ 7-603$, as amended 1955 Supp. (Italicized portions added by 1955 amendments.) Compare CaL. CIv. Cone $\$ 1858.27$ (1955 Supp.) (warehouse receipts), under which the adverse claimant must bring suit within forty-eight hours after notifying the warehouseman of his claim.

188. 3 Am. \& Evg. ENcyc. of LAw 762-63 (2d ed. 1897) ; Crawshay v. Thornton, 2 Myl. \& Cr. 1, 40 Eng. Rep. 541 (Ch. 1837).

189. Powell v. Robinson, 76 Ala. 423 (1884); Esmay v. Fanning, 9 Barb. 176 (N.Y. Sup. Ct. 1850) ; see Blaisdell v. Hersum \& Co., 233 Mass. 91, 123 N.E. 386 (1919). Section $7-403$ (1) (b) of the Code follows existing law, allowing the bailee to set up delivery to the true owner as a defense. Northwestern Cas. \& Surety Co. v. Illinois Cent. Ry., 19 F.2d 868 (7th Cir. 1927) ; Wheelock Bros., Inc. v. Bankers Warehouse Co., 115 Colo. 197, 171 P.2d 405 (1946) ; Miller v. New York Cent. R.R., 205 App. Div. 663, 200 N.Y. Supp. 287 (1st Dep't 1923).

190. Merz v. Northwestern Ry., 86 Minn. 33, 90 N.W. 7 (1902). Solomon v. Dawes, 1 Esp. R. 83, 170 Eng. Rep. 287 (N.P. 1794) ; see, e.g., Zuker v. Mehrle, 112 N.Y. Supp. 1093 (Sup. Ct. 1908) ; McKeehan, The Uniform Commercial Acts, 20 Dick. L. REv. 33, 74 (1915).

191. This procedure has been in common usage for over a century. See Pearson v. Cardon, 2 Russ. \& My. 606, 613, 39 Eng. Rep. 525, 528 (Ch. 1831) ; Morse-Hubbard Co. v. Michigan Cent. R.R., 286 Ill. App. 163, 168, 3 N.E.2d 93, 95 (1936) ; Bradley v. Illinois Cent. Ry., 291 Ky. 25, 163 S.W.2d 26 (1942).

192. U.B.I.A. $\$ \$ 20-21$; U.W.R.A. $\$ \$ 17-18$; New Jersey Title Guarantee and Trust Co. v. Rector, 76 N.J. Eq. 587, 75 Atl. 931 (Ct. Err. \& App. 1910) ; Manhattan Storage \& Warehouse Co. v. Benguiat Art Museum, 155 App. Div. 196, 139 N.Y. Supp. 1073 (1st Dep't 1913). Moreover, under the Uniform Acts, the possibility of an independent liability, see note 25 supra, will not preclude interpleader. Rosenberg v. Viane, Inc., 109 Misc. 215, 179 N.Y. Supp. 447 (Sup. Ct. 1919) ; Chafee, Federal Interpleader since the Act of 1036, 49 YALE L.J. 377, 412 (1940).

193. See note 187 supra. For a general comparison of Article 7 with the Uniform Acts, see Pryor, Article 7-Documents of Title: An Attempt at Commercial Unifonnity, 1952 Wrs. L. REv. 332. 
bailee is given a reasonable time to decide who is entitled to the goods; this means, in effect, that he may protect himself by delivering to either party upon an offer of indemnity. ${ }^{194}$

The result reached by the Code seems eminently sound. The bailee is seldom in a position to make a valid determination of the facts, or to resolve the complex problems of estoppel, agency or good faith purchase which may eventually defeat the claimant's rights. ${ }^{195}$ However, at least when both parties have equally plausible claims, and one has greater need to obtain the goods at once, commercial expediency demands that the goods should not be equally frozen for both. ${ }^{100}$ And there is no one in as good a position as the bailee to determine promptly which of the two claimants has the greater need for the goods. This determination will not subject the bailee to liability: although he delivers the goods "at his peril" if the document is not surrendered to him, ${ }^{197}$ he may deliver the goods and protect himself against liability by taking indemnity where there is need for immediate action. ${ }^{198}$ Moreover, requisites of honesty are met, even when the party who has not received the goods is eventually determined by a court to be the true owner, because of the protection of the indemnity bond. ${ }^{199}$ Where there is no need for haste, as in most noncommer-

194. Ward \& Farfield 62-63. The Code does not state that the bailee must deliver to either the claimant or the holder; he may be indemnified by either. See BrAUCHER, Documents of Titze 31 (1955). By contrast, in the stock transfer and commercial paper contexts the stakeholder must heed the claimant's offer of indemnity. U.C.C. $\$ \$ 3-603$, S-403.

Although delivery upon indemnity precludes interpleader, Mallory S.S. Co. v. Thalheim, 277 Fed. 196, 202-03 (2d Cir. 1921), the real parties in the subsequent action against the bailee are the adverse claimant and the holder. The bailee would be protected unless delivery were in such bad faith that the bailee would be liable for fraud or collusion in a civil or criminal suit. See Lawrence Warehouse Co. v. Twohig, 224 F.2d 493 (8th Cir. 1955) (participation in breach of trust); Henderson v. United States, 203 F.2d 81 (5th Cir. 1953) (criminal liability of warehouseman); U.C.C. $\$ \$ 1-103 ; 7-101$, comment. See Braucher, op. cit. supra at 33.

195. Swift v. Davis, 118 Misc. 205, 209, 193 N.Y. Supp. 848, 851 (Sup. Ct. 1922); Teller \& Co. v. American Ry. Express Co., 78 Pa. Super. 300, 303 (1922). See, e.g., Garrett Freight Lines v. Cornwall, 120 Utah 175, 232 P.2d 786 (1951) (contract dispute); U.C.C. $\$ 7-303$, comment 1 .

196. Fulda, Surrender of Documents of Title on Delivery of the Property, 25 CORNELL L.Q. 203, 215 (1940).

197. Wheelock Bros., Inc. v. Bankers Warehouse Co., 115 Colo. 197, 171 P.2d 405 (1946) ; Friednash v. Lawrence Warehouse Co., 121 Cal. App. 2d 202, 263 P.2d 45 (1954); Mercantile Trading Co. v. Roth, 350 Ill. App. 418, 113 N.E.2d 194 (1953); see U.C.C. $\$ 7-403(3)$; U.B.L.A. $\$ \S 13,15$; U.W.R.A. $\$ \S 10,11$.

198. The adverse claim provision follows other provisions of Article 7 which seek to insulate the stakeholder from all risks not directly concerned with the storage or transportation of goods. Texas Legrslative Council, Analyses of Articte 7 of the Uniform Commercial CODE 147 (1952). Since the bailee may be liable for conversion under $\$ 7-404$, the amount of the bond would have to exceed the value of the goods as stated in the bill of lading. See McCormick, Damages $\$ 123$ (1935).

199. See Braucher, Documents of Title 22 (1955); Fulda, supra note 196, at 216. In addition, licensed warehousemen are usually bonded under statute. See, e.g., State v. 
cial transactions, the bailee may resort to interpleader. Indeed, if the contending parties have no urgent need for the goods, they may both refuse indemnity and in effect compel the bailee to interplead. ${ }^{200}$

The length of time that the bailee may "reasonably" defer delivery upon notification of adverse claim should depend upon the type of claim made and the commercial context involved. ${ }^{201}$ To a large extent, the Code implicitly recognizes the need of such flexibility in this area. Thus, judgment creditors making claims to the goods are obliged to enjoin delivery to a holder. ${ }^{202}$ The time element here is not nearly so important as it is in commercial transactions, and the holder is therefore given fuller protection and may obtain delivery unless the judgment creditor has procured the document. Conversely, when the bailee is a carrier and the goods are in transit, section 7-303 allows the bailee to follow the holder's instructions and disregard all others. ${ }^{203}$ These provisions provide a desirably automatic course of action where it is needed; the time factor when goods are in transit renders inexpedient the flexibility which, in warehousing, best meets commercial demands. ${ }^{204}$

\section{ConCLUSION}

The Uniform Commercial Code's treatment of adverse claims marks a significant improvement over existing statutory and case law methods of resolving conflicts between the dictates of honesty and negotiability in commercial law. The adverse claim provisions have generally freed the stakeholder from the impracticable duty of protecting "equities" which have not, when asserted,

Dalrymple, 227 Minn. 533, 35 N.W.2d 714 (1949). Under some circumstances, the claimant will also be able to attach the goods or enjoin delivery. For example, if the claimant has not authorized the bailment, he may reach the goods by obtaining a court order. If, however, the claim occurs during the bailment, neither an attachment nor an injunction is effective unless the claimant has been able to compel surrender of an outstanding negotiable document. See Eyre \& Co. v. Hirsch, 36 Wash. 2d 439, 218 P.2d 888 (1950); U.C.C. § 7-602; U.B.L.A. § 24 ; U.W.R.A. \$ 25.

200. See 2 Williston, Sales 594 (rev. ed. 1948) ; cf. note 191 supra and accompanying text.

201. Covlin v. Volochenko, 53 N.D. 6, 204 N.W. 892 (1925); see cases cited note 181 supra.

When the bailee has constructive notice of an adverse claim, $\$ 7-404$, by implication, would hold the bailee liable for conversion if delivery to the holder were neither in good faith nor in the "observance of reasonable commercial standards." For a statement of existing law, which is similar, see 2 Wrusiston, Sales 593 (rev. ed. 1948) (collecting citations) ; Lawrence Warehouse Co. v. Twohig, 224 F.2d 493 (8th Cir. 1955) ; Investment Serv. Co. v. O'Brien, 190 Ore. 394, 223 P.2d 163 (1950). Contra, L. Fish Furniture Co. v. Reliable Storage \& Van Co., 187 I1l. App. 6 (1914).

202. U.C.C. $\$ 7-602$; see note 199 supra.

203. When the bill of lading is nonnegotiable, the carrier may take the orders of the consignor. U.C.C. \$ 7-303(1) (b). See Louisville \& N.R.R. v. Campbell Lumber Co., 45 Ga. App. 851, 166 S.E. 252 (1932) ; Getchell v. Northwestern Pac. Ry., 110 Wash. 66, 187 Pac. 707 (1920).

204. See Ahearn, Freight Forwarders and Common Carriage, 15 FordHam L. Rev. 248 (1.946). 
withstood the test of litigation. The stakeholder is treated not as an arbiter of adverse claims but as a channel through which business is transacted. This treatment should be extended, however, to areas in which problems of fiduciary relationships and constructive notice are present. The stakeholder is equally unequipped to judge the merits of claims in these areas, and the claimant has other means of protection available to him. Moreover, only half the problem is solved by relieving the stakeholder of a possible double liability. The Code should also reconcile the protection of the adverse claimant with the commercially desirable presumption that negotiable paper has been purchased in good faith. In this respect the Code provisions allowing the claimant to stop payment to the holder by an offer of indemnity have undervalued the interests of the holder, who should not be forced to initiate litigation to assert his rights. Except for adverse claims arising in the context of documents of title, where the documents represent goods in commerce, the demands of the stakeholder, the claimant and the holder would be better adjusted to the needs of commercial transactions by relieving the stakeholder from discretion and a possible double liability, permitting the holder to obtain payment without substantial delay, and guaranteeing the claimant an opportunity to serve process on the holder when he presents the negotiable item for payment or registration. 